NBER WORKING PAPER SERIES

\title{
UNDERSTANDING DEFENSIVE EQUITY
}

\author{
Robert Novy-Marx \\ Working Paper 20591 \\ http://www.nber.org/papers/w20591 \\ NATIONAL BUREAU OF ECONOMIC RESEARCH \\ 1050 Massachusetts Avenue \\ Cambridge, MA 02138 \\ October 2014
}

The views expressed herein are those of the author and do not necessarily reflect the views of the National Bureau of Economic Research.

NBER working papers are circulated for discussion and comment purposes. They have not been peerreviewed or been subject to the review by the NBER Board of Directors that accompanies official NBER publications.

(C) 2014 by Robert Novy-Marx. All rights reserved. Short sections of text, not to exceed two paragraphs, may be quoted without explicit permission provided that full credit, including $\bigcirc$ notice, is given to the source. 
Understanding Defensive Equity

Robert Novy-Marx

NBER Working Paper No. 20591

October 2014

JEL No. G12

\begin{abstract}
$\underline{\text { ABSTRACT }}$
High volatility and high beta stocks tilt strongly to small, unprofitable, and growth firms. These tilts explain the poor absolute performance of the most aggressive stocks. In conjunction with the well documented inability of the Fama and French three-factor model to price small growth stocks, especially unprofitable small growth stocks, these tilts also drive the abnormal performance of defensive equity (i.e., low volatility and/or low beta strategies). While defensive strategy performance is explained by controlling for size, profitability, and relative valuations, the converse is false - the performance of value and profitability strategies cannot by explained using defensive equity performance.
\end{abstract}

Robert Novy-Marx

Simon Graduate School of Business

University of Rochester

305 Schlegel Hall

Rochester, NY 14627

and NBER

Robert.Novy-Marx@Simon.Rochester.edu 


\section{Introduction}

Defensive equity strategies have seen explosive growth over the last five years. These strategies overweight "safe" or "defensive" stocks, and under-weight "risky" or "aggressive" stocks, where these are typically defined by a stock's volatility or market beta. Their popularity has been encouraged by the convergence of two factors: an equity market that delivered two severe bear markets and negative nominal returns over the first decade of the twenty-first century, and a growing academic literature documenting a weak or negative relation between equities' risks and returns.

Low beta strategies were first suggested by Fischer Black (1972), who unsuccessfully lobbied Wells Fargo to establish a levered low beta fund in the early 1970s. A more recent surge in academic interest was spurred by Ang et. al.'s (2006) finding of a negative relation between idiosyncratic volatility and subsequent stock returns, the so-called "idiosyncratic volatility puzzle." The most influential of the subsequent work includes Blitz and Van Vliet (2007), which considered the performance of portfolios sorted on total volatility; Baker, Bradley, and Wurgler (2011), which documents the modern performance of strategies based on both low volatility and low market beta; and Frazzini and Pedersen (2014), which introduces "betting-against-beta," a sophisticated dynamic version of Black's beta-arbitrage.

Low volatility and low beta strategies are popular with institutional investors, pension funds, and insurance companies. Retail defensive equity funds have also seen robust inflows, and compete with "quality" strategies and managed futures as the new strategies most favored by active managers. The interest defensive strategies have received in both academia and on Wall Street have led some to call for raising them into the canon of the most important market anomalies. Frazzini and Pedersen (2014) claim, for example, that the return to their betting-against-beta strategy "rivals those of all the standard asset pricing factors (e.g., value, momentum, and size) in terms of economic magnitude, statistical significance, and robustness." Baker, Bradley, and Wurgler (2011) go even further, opining that "among the many candidates for the greatest anomaly in finance, a particularly compelling one is the long-term success of low-volatility and low-beta stock portfolios." 
This paper takes a more skeptical view. While reaffirming the poor absolute performance of the most aggressive stocks, it nevertheless shows that the performance of defensive equity strategies is explained by known drivers of cross-sectional variation in returns. This is somewhat surprising, as previous work, including Blitz and Van Vliet (2007) and Asness, Frazzini, and Pedersen (2014), explicitly reject the hypothesis that defensive strategy performance is driven by size and value effects. This earlier work fails to account for profitability, however, which is an essential ingredient for understanding defensive strategy performance.

High profitability is, next to large market capitalization, the single best predictor of low volatility. Defensive strategies consequently tilt strongly towards profitability. This also tends to obscure the true extent to which defensive strategies tilt toward value. Because profitability and value tend to be strongly negatively correlated, the large profitability loadings on defensive strategies reduce the defensive strategies' loadings on value strategies in tests that fail to control for profitability. Accounting for profitability, and the true extent to which defensive strategies tilt toward value, are crucial for explaining defensive strategy performance.

Small growth stocks also play a critical role in defensive equity. Defensive strategies overweight large value stocks and underweight small growth stocks, which contributes directly to defensive strategy performance. Small growth additionally drives defensive strategy performance through a second, indirect channel: within style universes, defensive strategy performance is strongly concentrated in the small growth segment. In fact, defensive stocks only outperform aggressive stocks in the small growth segment; aggressive stocks actually significantly outperform defensive stocks in large value.

The success of defensive strategies among small growth firms is consistent with profitability and value driving their performance. The small growth sector is also where volatility is most strongly associated with valuations and profitability-low volatility stocks in the small growth sector have only moderately high valuations and are quite profitable, while high volatility stocks in this sector on average have both negative book equity and negative earnings. Because of the large variation in valuations and profitability between high and low volatility small growth stocks, the performance of defensive strategies constructed 
in the small growth universe far exceeds the performance of defensive strategies formed in the broad market. The performance of these small growth defensive strategies nevertheless lags the performance of strategies constructed in the small growth segment that exploit direct variation in valuations and profitability. More generally, accounting for size, relative valuations, and profitability, completely explains the performance of defensive strategies.

This is not to say that an individual would not have benefited from following a defensive strategy. Investors certainly would have profited from avoiding unprofitable small cap growth firms. Defensive strategies are, however, an inefficient way to exploit these premia, which are better accessed directly. The backdoor route defensive strategies provide to an unprofitable small growth exclusion is also transactionally inefficient, entailing significant rebalancing and high transaction costs (Li, Sullivan, Garcia-Feijóo, 2014).

The rest of the paper is organized as follows. Section 2 analyzes the performance of portfolios formed on the basis of volatility and estimated market beta, and looks at the style tilts in these portfolios. Section 3 shows that the performance of defensive strategies is explained by controlling for size, value, and profitability. Section 4 investigates the critical role small cap growth stocks play in defensive style performance. Section 5 shows that these results are robust to controlling for time variation in style tilts, by analyzing the performance of defensive strategies dynamically hedged of factor exposures. Section 6 concludes.

\section{Defensive strategy performance}

Figure 1 shows the performance of quintile portfolios formed on the basis of estimated volatilities (Panel A) and market betas (Panel B). Volatilities and betas are estimated each month using one year of daily data. Quintiles are formed each month using NYSE breakpoints. ${ }^{1}$ Portfolio returns are value-weighted, and ignore transaction costs. Following Baker, Bradley, and Wurgler (2008), the sample begins in January 1968. This start date basically

\footnotetext{
${ }^{1}$ I use NYSE breaks, instead of the CRSP breaks employed in Baker, Bradley, and Wurgler (2008), because of strong size biases in the volatility portfolios. Using CRSP breaks yields extreme tilts, with an end of the sample average market cap in the high volatility quintile of only $\$ 33$ million, and the entire quintile making up on average less than $1.2 \%$ of total market capitalization. See Bali and Cakici (2008) for a more detailed analysis of the differences in volatility strategy performance using CRSP and NYSE breaks.
} 

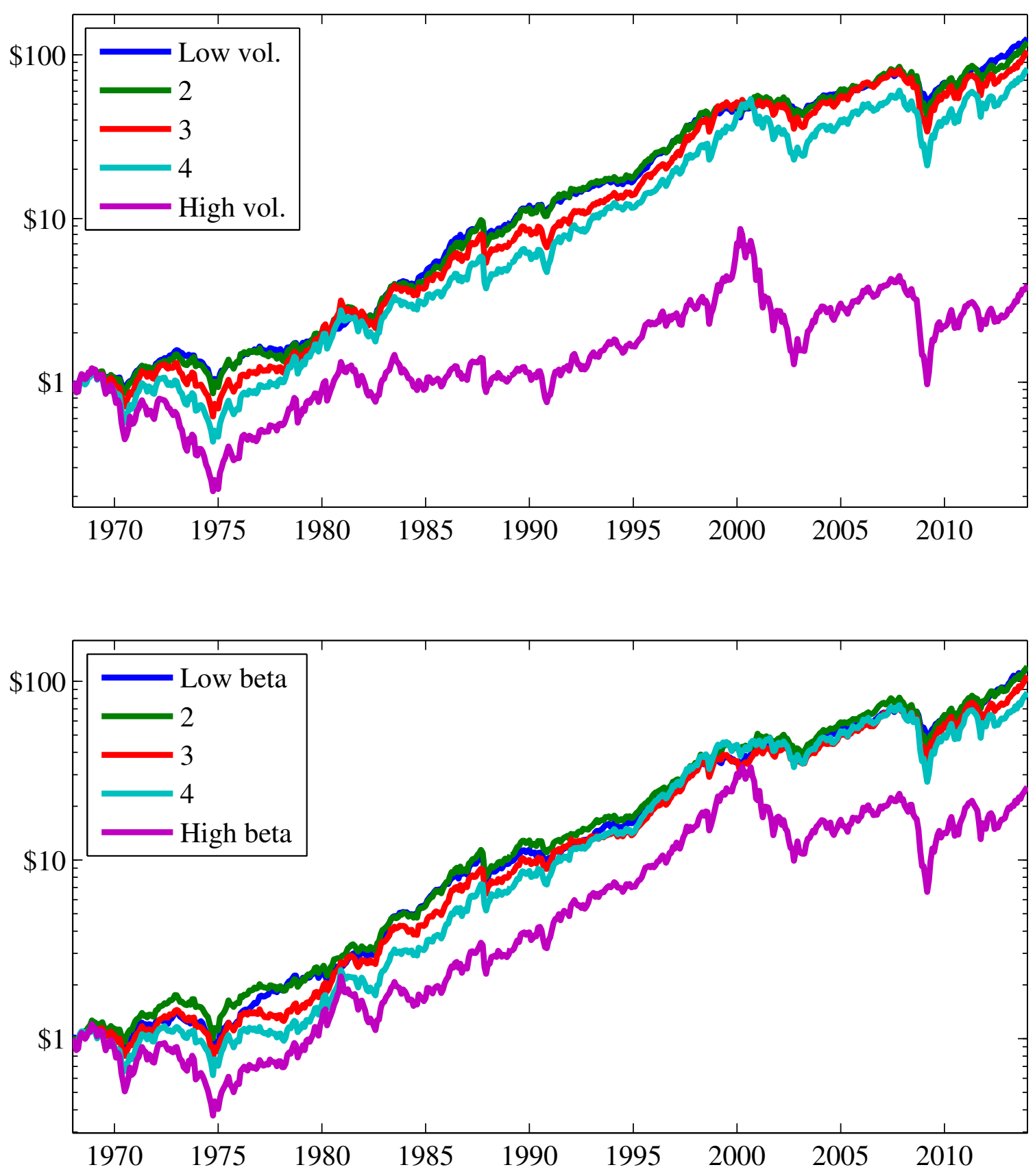

Figure 1. Performance of volatility and beta quintiles

Growth of $\$ 1$ invested in quintile portfolios sorted on volatility (top panel) and beta (bottom panel). Portfolios are rebalanced monthly and ignore transaction costs, and returns are value-weighted. The sample covers January 1968 through December 2013. 
coincides with the date at which high volatility stocks began underperforming low volatility stocks, and thus bias the results toward finding impressive defensive strategy performance (see Appendix A for pre-1968 performance).

The figure shows that the most aggressive stocks, i.e. those in the high volatility or high market beta quintile, have dramatically underperformed the rest of the market. This underperformance is especially pronounced for the high volatility portfolio. In both panels the figure shows little variation in performance between the other four portfolios, which all closely track the market.

Figure 2 shows Morningstar-type style boxes for the aggressive and defensive portfolios, defined using both volatility (Panel A) and market beta (Panel B). Formally the figure shows log-likelihood ratios that a stock picked at random from one of the defensive or aggressive volatility or beta portfolios is in particular size and value quintiles (defined using NYSE breaks), relative to the likelihood that a stock picked at random from the entire universe is in the same size and value quintiles. That is, the log-likelihood ratio $L L R_{i j k}$ that a stock in risk quintile $k$ is in size quintile $i$ and value quintile $j$ is given by

$$
L L R_{i j k}=\log \left(\frac{P\left[s_{l t} \in \mathrm{ME}_{i t} \cap \mathrm{BM}_{j t} \mid s_{l t} \in \mathrm{R}_{k t}\right]}{P\left[s_{l t} \in \mathrm{ME}_{i t} \cap \mathrm{BM}_{j t}\right]}\right),
$$

where $s_{l t}$ is the stock of a random firm $l$ picked at a random time $t$, and $\mathrm{ME}_{i t}, \mathrm{BM}_{j t}$, and $\mathrm{R}_{k t}$ are market equity quintile $i$, book-to-market quintile $j$, and risk quintile $k$, respectively, all at time- $t$. The data underlying the figure are reported in Table 8, in the appendix.

The figure shows strong size and value tilts to the defensive and aggressive portfolios. These are especially pronounced in the portfolios formed on the basis of volatility. The left half of Panel A shows a growth tilt, and an extreme tilt toward small caps, for the high volatility portfolio. The right half shows a strong value tilt, and an extreme tilt toward large caps, for the low volatility portfolio. Panel B shows a growth tilt to the high beta portfolios, and small cap and value tilts to the low beta portfolios, though these tilts are less extreme than those observed on the volatility portfolios. 
Panel A: Portfolios formed on volatility


Panel B: Portfolios formed on estimated market betas
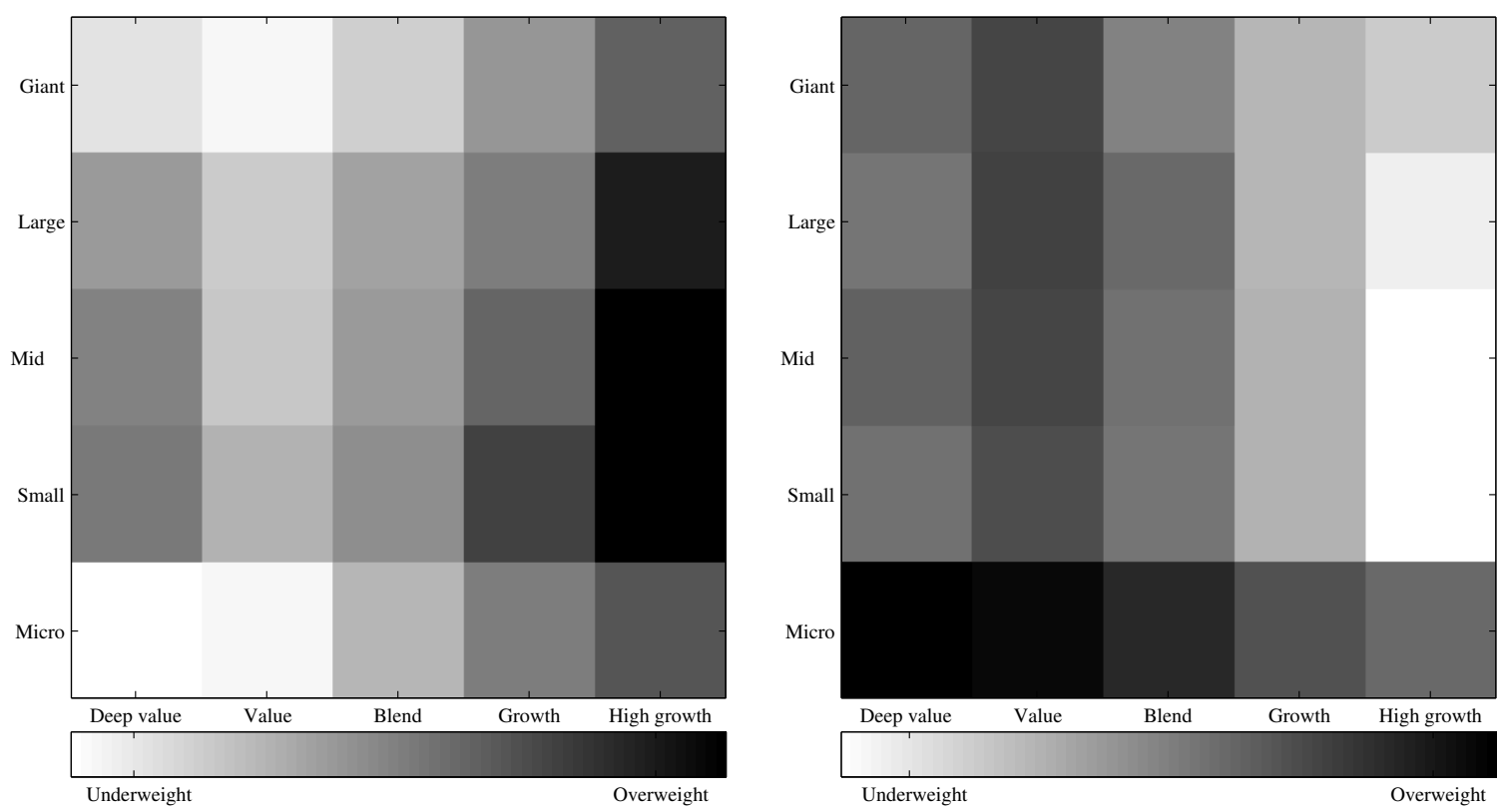

\section{Figure 2. Volatility and beta portfolio style boxes}

The figure shows log-likelihood ratios that a randomly selected stock from one of the volatility or beta quintile portfolios is of a given style (size and value quintile, using NYSE breaks), relative to the unconditional probability of being that style. The sample covers January 1968 through December 2013. Underlying probabilities are provided in Table 8 in the appendix. 
The tilts observed in Figure 2 can also be seen in Tables 1 and 2, which formally analyze the performance of the volatility and beta portfolios shown in Figure 1. Panel A gives volatility portfolio characteristics. It does not show significant variation in the time-series average valuations of the low and high volatility portfolios, but shows enormous variation in firm size across portfolios. The low volatility stocks are on average more than 25 times as large as the high volatility stocks at the end of the sample. As a result the high volatility portfolio on average holds less than nine percent of the market by capitalization, despite holding almost half of stocks by name. Panel B shows that the average returns across volatility portfolios are basically flat, or even slightly increasing with volatility, with the exception of the extremely low returns to the most aggressive stocks. Panel $\mathrm{C}$ shows the typical Black, Jensen, and Scholes (1972) failure of the CAPM, with a significant negative alpha for the high volatility/high beta portfolio, and a significant positive alpha for the low volatility/low beta portfolio. Panel D shows results of Fama and French (1993) three-factor regressions using the volatility portfolio returns, and provides further evidence of the size and value tilts in the defensive strategies. The long/short strategy has a large value tilt (HML loading of 0.42), and an enormous large cap tilt (SMB loading of -1.12). Despite the highly significant factor loadings, the three-factor model is unable to price the defensive strategy, which generates three-factor abnormal returns of 68 basis points per month (t-stat of 4.29). Five-sixths of this alpha (57 out of $68 \mathrm{bps} / \mathrm{month}$ ) is delivered, however, by the aggressive stocks on the short side of the strategy, with only one-sixth, or eleven basis points per month, coming from the actual defensive stocks.

Table 2 shows similar, though less challenging, results for the portfolios sorted on estimated market betas. The table provides evidence of larger value tilts, though smaller size tilts, to the beta portfolios. It also shows that while the anti-beta strategy generates a significant CAPM alpha, it does not deliver significant abnormal returns after controlling for exposures to the size and value factors. Because the volatility strategies present a challenge to the standard three-factor model while the beta strategies do not, the remainder of the paper focuses on the former, relegating test results for beta strategies to the appendix. 
Table 1. Volatility portfolio performance

The table reports time-series average characteristics (Panel A), monthly average excess returns (Panel B), and results of time-series regressions using the CAPM and the Fama and French three-factor model (Panels C and D, respectively), of quintile portfolios sorted on volatility. Portfolios are rebalanced monthly using NYSE breaks. Returns are value-weighted, and ignore transaction costs. The sample includes all NYSE, NASDAQ, and AMEX common stocks, and covers January 1968 through December 2013.

Volatility quintiles

$\begin{array}{llllll}(\mathrm{H}) & (2) & (3) & (4) & (\mathrm{L}) & (\mathrm{L}-\mathrm{H})\end{array}$

Panel A: Portfolio characteristics

$\begin{array}{lccccc}\text { Firms }(\%) & 49.5 & 15.5 & 11.5 & 9.99 & 13.5 \\ \text { Cap. }(\%) & 8.6 & 10.7 & 16.7 & 25.7 & 38.3 \\ \mathrm{~B} / \mathrm{M} & 0.65 & 0.63 & 0.63 & 0.60 & 0.65 \\ \overline{\mathrm{ME}}_{2013}\left(\$ 10^{6}\right) & 84 & 204 & 709 & 931 & 2,209\end{array}$

Panel B: Portfolio average monthly excess returns

$\begin{array}{ccccccc}\mathrm{E}\left[R^{e}\right] & 0.19 & 0.59 & 0.57 & 0.55 & 0.52 & 0.33 \\ & {[0.53]} & {[2.14]} & {[2.46]} & {[2.83]} & {[3.44]} & {[1.13]}\end{array}$

Panel C: CAPM regression results

$\begin{array}{lcccccc}\alpha & -0.59 & -0.05 & 0.03 & 0.10 & 0.19 & 0.78 \\ & {[-3.52]} & {[-0.60]} & {[0.42]} & {[1.57]} & {[2.77]} & {[3.52]} \\ \beta_{\text {MKT }} & 1.63 & 1.34 & 1.14 & 0.94 & 0.68 & -0.95 \\ & {[45.0]} & {[72.3]} & {[78.0]} & {[67.7]} & {[46.3]} & {[-19.8]} \\ \text { Adj.- } R^{2}(\%) & 78.6 & 90.5 & 91.7 & 89.3 & 79.6 & 41.6\end{array}$

Panel D: Three-factor model regression results

\begin{tabular}{lcccccc}
$\alpha$ & -0.57 & -0.11 & -0.04 & 0.03 & 0.11 & 0.68 \\
& {$[-4.69]$} & {$[-1.40]$} & {$[-0.57]$} & {$[0.47]$} & {$[2.02]$} & {$[4.29]$} \\
$\beta_{\text {MKT }}$ & 1.41 & 1.28 & 1.17 & 1.02 & 0.78 & -0.63 \\
& {$[50.5]$} & {$[73.1]$} & {$[75.6]$} & {$[79.4]$} & {$[61.5]$} & {$[-17.4]$} \\
$\beta_{\text {SMB }}$ & 0.88 & 0.34 & -0.01 & -0.18 & -0.24 & -1.12 \\
\multirow{3}{*}{$\beta_{\text {HML }}$} & {$[22.1]$} & {$[13.5]$} & {$[-0.28]$} & {$[-9.72]$} & {$[-13.3]$} & {$[-21.5]$} \\
\multirow{2}{*}{ Adj.- $R^{2}(\%)$} & -0.21 & 0.05 & 0.14 & 0.19 & 0.21 & 0.42 \\
& {$[-5.05]$} & {$[1.86]$} & {$[5.80]$} & {$[9.62]$} & {$[10.7]$} & {$[7.59]$} \\
& 89.4 & 92.9 & 92.2 & 92.4 & 87.5 & 71.7 \\
\hline
\end{tabular}


Table 2. Beta portfolio performance

The table reports time-series average characteristics (Panel A), monthly average excess returns (Panel B), and results of time-series regressions using the CAPM and the Fama and French three-factor model (Panels C and D, respectively), of quintile portfolios sorted on market beta. Portfolios are rebalanced monthly using NYSE breaks. Returns are value-weighted, and ignore transaction costs. The sample includes all NYSE, NASDAQ, and AMEX common stocks, and covers January 1968 through December 2013.

\begin{tabular}{lllllll}
\hline \multicolumn{7}{c}{ Beta quintiles } \\
\cline { 2 - 5 } & $(\mathrm{H})$ & $(2)$ & $(3)$ & $(4)$ & $(\mathrm{L})$ & $(\mathrm{L}-\mathrm{H})$ \\
\hline
\end{tabular}

Panel A: Portfolio characteristics

$\begin{array}{llllll}\text { Firms (\%) } & 19.5 & 14.9 & 15.0 & 17.0 & 33.6 \\ \text { Cap. }(\%) & 18.6 & 20.3 & 21.8 & 21.1 & 18.2 \\ \text { B/M } & 0.58 & 0.60 & 0.61 & 0.68 & 0.76 \\ \overline{M E}_{2013}\left(\$ 10^{6}\right) & 355 & 565 & 706 & 826 & 543\end{array}$

Panel B: Portfolio average monthly excess returns

$\begin{array}{ccccccc}\mathrm{E}\left[R^{e}\right] & 0.44 & 0.54 & 0.53 & 0.53 & 0.51 & 0.07 \\ & {[1.40]} & {[2.29]} & {[2.74]} & {[3.15]} & {[3.37]} & {[0.28]}\end{array}$

Panel C: CAPM regression results

$\begin{array}{lcccccc}\alpha & -0.28 & -0.00 & 0.09 & 0.16 & 0.22 & 0.50 \\ & {[-2.66]} & {[-0.04]} & {[1.25]} & {[2.17]} & {[2.34]} & {[2.88]} \\ \beta_{\text {MKT }} & 1.50 & 1.14 & 0.91 & 0.76 & 0.61 & -0.89 \\ & {[65.4]} & {[67.4]} & {[57.6]} & {[48.4]} & {[30.7]} & {[-24.0]} \\ \text { Adj.- } R^{2}(\%) & 88.6 & 89.2 & 85.8 & 81.0 & 63.1 & 51.2\end{array}$

Panel D: Three-factor model regression results

\begin{tabular}{lcccccc}
$\alpha$ & -0.24 & -0.09 & -0.03 & 0.03 & 0.04 & 0.28 \\
$\beta_{\text {MKT }}$ & {$[-2.39]$} & {$[-1.27]$} & {$[-0.39]$} & {$[0.45]$} & {$[0.47]$} & {$[1.76]$} \\
& 1.43 & 1.19 & 0.99 & 0.83 & 0.68 & -0.74 \\
$\beta_{\text {SMB }}$ & {$[60.6]$} & {$[68.8]$} & {$[66.3]$} & {$[55.8]$} & {$[36.1]$} & {$[-20.1]$} \\
& 0.24 & -0.06 & -0.12 & -0.07 & -0.01 & -0.24 \\
$\beta_{\text {HML }}$ & {$[7.00]$} & {$[-2.56]$} & {$[-5.45]$} & {$[-3.20]$} & {$[-0.28]$} & {$[-4.60]$} \\
& -0.12 & 0.20 & 0.26 & 0.28 & 0.37 & 0.49 \\
Adj.- $R^{2}(\%)$ & {$[-3.44]$} & {$[7.55]$} & {$[11.5]$} & {$[12.3]$} & {$[12.7]$} & {$[8.65]$} \\
\hline
\end{tabular}




\subsection{Defensive strategy style drivers}

Table 3 shows results of Fama and MacBeth (1973) regressions of volatility onto variables known to predict cross-sectional variation in returns (similar results using the other dominant defensive indicator, estimated market beta, as the dependent variable are shown in the Appendix, in Table 9). It also shows results using leverage as the explanatory variable, because low leverage is frequently employed in industry as an additional defensive signal. The results of the table help explain the style tilts observed in Figure 1 and 2, and provides further insights into the underlying nature of defensive equity.

Specification (1) shows the highly significant negative correlation between volatility and size, and explains why stocks picked on the basis of low volatility tend to be large. Specification (2) shows that there is not a significant univariate correlation between volatility and valuations.

Specification (3) shows that defensive strategies tilt toward high profitability. Enterpriselevel operating profitability, defined as revenues minus costs of goods sold minus selling, general and administrative expenses, all scaled by assets, is an even more significant negative predictor of volatility than size. Novy-Marx's (2013) gross profitability, Fama and French's (2014) book-level operating profitability, Ball et. al.'s (2014) R\&D adjusted assetlevel operating profitability, and even simple net income-to-book equity (ROE), are all highly significant negative predictors of volatility. I employ enterprise-level operating profitability here, and for all further discussions of profitability, for the simple expediency that it is this measure that empirically has the most power explaining volatility. The power profitability has forecasting expected returns is robust across profitability specification, and the measure employed here has similar power explaining cross-sectional variation in returns to gross profitability. For more on the performance of portfolios sorted on enterprise level operating profitability, and for tests employing alternative measures of profitability to predict volatility, see Appendix Tables 10 and 11.

Specification (4) shows that leverage, at least as a univariate predictor, also has power explaining volatility — higher levels of leverage are significantly associated with higher volatilities. 


\section{Table 3. Volatility correlates}

The table reports Fama and MacBeth (1973) regressions of volatility onto variables known to predict crosssectional variation in returns. Because of the persistence in the variables Newey and West t-statistics are reported, calculated using 60 monthly lags. The sample covers January 1968 through December 2013.

\begin{tabular}{lccccc}
\hline Predictor variable & $(1)$ & $(2)$ & $(3)$ & $(4)$ & $(5)$ \\
\hline Size $(\ln (\mathrm{ME}))$ & -0.08 & & & & -0.08 \\
& {$[-9.63]$} & & & & {$[-8.74]$} \\
Value $(\ln (\mathrm{B} / \mathrm{M}))$ & & -0.01 & & & -0.05 \\
& & {$[-0.78]$} & & & {$[-5.92]$} \\
Profitability $\left(\frac{\mathrm{GP}-\mathrm{SGA}}{\mathrm{A}}\right)$ & & & -0.45 & & -0.37 \\
& & & {$[-10.2]$} & & {$[-13.6]$} \\
Leverage (B/A) & & & & -0.09 & 0.05 \\
& & & & {$[-6.49]$} & {$[1.09]$} \\
Mean- $R^{2}(\%)$ & 25.1 & 2.9 & 9.3 & 1.5 & 36.7 \\
\hline
\end{tabular}

Specification (5) shows results of regressions that employ all four explanatory variables. Its most interesting feature is that valuations, after controlling for size and profitability, become highly significant correlates of volatility. Highly volatile stocks tend to be not only small, but also unprofitable, and to carry high valuations. The insignificant coefficient on valuations in specification (3), and the relatively modest HML loading on the defensive strategy in Table 1, result from failing to control for profitability, together with the significant negative correlation between profitability and valuations. That is, while value stocks are on average less volatile, holding all else equal, value stocks also tend to be smaller and less profitable, and smaller and less profitable stocks tend to be more volatile. These size and profitability tilts tend to obscure the true magnitude of the role value plays in defensive strategies. Specification (5) also shows that there is no significant role played by leverage after accounting for size, valuations, and profitability.

Because defensive stocks tend to be more profitable, and because they also tilt more to value than one would think after controlling for profitability, controlling for these effects is crucial for understanding the performance of defensive strategies. 


\section{Defensive strategy performance controlling for size}

Controlling for size is critical when analyzing strategies based on volatility, because the size biases observed in the unconditional sorts on volatility (Table 1) are particularly extreme. The size bias also interacts with value, which has experienced much stronger performance among small cap stocks. Table 4 controls for size by constructing defensive strategies within size universes. ${ }^{2}$

At the start of each month firms are assigned to size portfolios, defined by NYSE market cap deciles (size portfolios characteristics provided in Panel A of Table 4). Within each size decile a defensive-minus-aggressive (DMA) strategy is formed, by buying (selling) the $30 \%$ of stocks with the lowest (highest) estimated volatility. Returns are again value-weighted, and ignore transaction costs. ${ }^{3}$ Panel B of Table 4 shows that the average monthly excess returns to the ten DMA strategies was almost 50 basis points per month. While this performance was somewhat concentrated in the lowest three size deciles, which make up on average just 5.4 percent of the market by capitalization, performance was positive in every size decile, and a Gibbons, Ross, and Shanken (GRS, 1989) test rejects the null that the excess returns are jointly zero at the one percent level. Panel $\mathrm{C}$ shows that the strategies on average have loadings of -0.84 on the market, leading to all ten strategies having highly significant CAPM alphas, which average 90 basis points per month.

Panel D shows that the Fama and French model explains much more of the strategies' return variation than the CAPM, an average of $61.4 \%$ compared to $36.1 \%$, but explains less than a third of the strategies' average returns. The three factor model has some success pricing the defensive strategies in the three largest size deciles, which make up on average $80 \%$ of the market by capitalization, but even among these large cap stocks the defensive strategies deliver positive, though insignificant, abnormal returns.

\footnotetext{
${ }^{2}$ Controlling for size is equally important when analyzing strategies based on market beta. For example, the signal weighting procedure employed by Frazzini and Pedersen (2014), which overweights small stocks even more than an equal-weighting scheme, is a crucial driver of the performance of their beta-based BAB factor. Results of tests similar to those presented in Table 4, using defensive strategies constructed within size deciles on the basis of estimated market beta instead of volatility, are provide in the Appendix in Table 12.

${ }^{3}$ I use the top and bottom $30 \%$ when constructing these strategies inside the size portfolios. The largest size deciles contain only about 200 names at the end of the sample, and even fewer in the early sample. A more extreme second sort consequence yields poorly diversified strategies.
} 


\section{Table 4. Volatility portfolio performance by size deciles}

The table reports the performance of defensive-minus-aggressive (DMA) strategies, constructed within each NYSE size decile by buying (selling) the $30 \%$ of stocks with the lowest (highest) estimated volatility. It also reports performance of the strategies relative to the CAPM, the Fama and French three-factor model, and relative to the market and similarly constructed profitability and value strategies (profitable-minus-unprofitable [PMU] and value-minus-growth [VMG], formed on the basis of profitability ([GP-SGA]/A) and valuations (B/M), respectively). All portfolios are rebalanced monthly, and returns are value-weighted and ignore transaction costs. The sample covers January 1986 to December 2013.

\begin{tabular}{llllllllllll}
\hline \multicolumn{10}{c}{ Size decile } \\
\cline { 2 - 5 } & $(1)$ & $(2)$ & $(3)$ & $(4)$ & $(5)$ & (6) & $(7)$ & (8) & (9) & (10)
\end{tabular}

Panel A: Size portfolio characteristics

$\begin{array}{lcccccccccc}\text { Names }(\%) & 48.7 & 12.2 & 8.1 & 6.4 & 5.4 & 4.5 & 4.1 & 3.8 & 3.5 & 3.4 \\ \text { Cap. }(\%) & 1.8 & 1.7 & 1.9 & 2.4 & 3.0 & 3.8 & 5.2 & 8.0 & 13.7 & 58.5 \\ \text { ME }_{2013}\left(\$ 10^{6}\right) & 13 & 53 & 93 & 148 & 224 & 330 & 488 & 806 & 1,613 & 7,812\end{array}$

Panel B: Volatility strategy average monthly excess returns, by size deciles

\begin{tabular}{|c|c|c|c|c|c|c|c|c|c|c|c|}
\hline $\mathrm{E}\left[\mathrm{DMA}_{i}\right]$ & $\begin{array}{c}1.12 \\
{[3.73]}\end{array}$ & $\begin{array}{c}0.78 \\
{[2.77]}\end{array}$ & $\begin{array}{c}0.70 \\
{[2.38]}\end{array}$ & $\begin{array}{c}0.55 \\
{[1.92]}\end{array}$ & $\begin{array}{c}0.44 \\
{[1.56]}\end{array}$ & $\begin{array}{c}0.40 \\
{[1.46]}\end{array}$ & $\begin{array}{c}0.32 \\
{[1.16]}\end{array}$ & $\begin{array}{c}0.16 \\
{[0.60]}\end{array}$ & $\begin{array}{c}0.30 \\
{[1.13]}\end{array}$ & $\begin{array}{c}0.15 \\
{[0.69]}\end{array}$ & 0.49 \\
\hline \multicolumn{12}{|c|}{ GRS p-value: $0.9 \%$} \\
\hline \multicolumn{12}{|c|}{ Panel C: CAPM regression results } \\
\hline$\alpha$ & $\begin{array}{c}1.49 \\
{[5.74]}\end{array}$ & $\begin{array}{c}1.22 \\
{[5.56]}\end{array}$ & $\begin{array}{c}1.15 \\
{[5.04]}\end{array}$ & $\begin{array}{c}1.00 \\
{[4.47]}\end{array}$ & $\begin{array}{c}0.88 \\
{[3.95]}\end{array}$ & $\begin{array}{c}0.81 \\
{[3.73]}\end{array}$ & $\begin{array}{c}0.71 \\
{[3.14]}\end{array}$ & $\begin{array}{c}0.57 \\
{[2.56]}\end{array}$ & $\begin{array}{c}0.66 \\
{[3.07]}\end{array}$ & $\begin{array}{c}0.48 \\
{[2.70]}\end{array}$ & 0.90 \\
\hline$\beta_{\mathrm{MKT}}$ & $\begin{array}{c}-0.78 \\
{[-13.8]}\end{array}$ & $\begin{array}{c}-0.91 \\
{[-19.3]}\end{array}$ & $\begin{array}{c}-0.95 \\
{[-19.2]}\end{array}$ & $\begin{array}{c}-0.93 \\
{[-19.3]}\end{array}$ & $\begin{array}{c}-0.90 \\
{[-18.9]}\end{array}$ & $\begin{array}{c}-0.86 \\
{[-18.3]}\end{array}$ & $\begin{array}{c}-0.81 \\
{[-16.7]}\end{array}$ & $\begin{array}{c}-0.84 \\
{[-17.6]}\end{array}$ & $\begin{array}{c}-0.76 \\
{[-16.4]}\end{array}$ & $\begin{array}{c}-0.68 \\
{[-17.7]}\end{array}$ & -0.84 \\
\hline Adj.- $R^{2}(\%)$ & 25.6 & 40.2 & 40.0 & 40.3 & 39.3 & 37.7 & 33.4 & 35.8 & 32.7 & 36.2 & 36.1 \\
\hline
\end{tabular}


Table 4 (continued)

\begin{tabular}{clllllllllll}
\hline \multicolumn{1}{c}{ Size decile } \\
\cline { 2 - 5 } & $(1)$ & $(2)$ & $(3)$ & $(4)$ & $(5)$ & (6) & $(7)$ & (8) & (9) & (10) & Mean
\end{tabular}

Panel D: Fama and French three-factor model regression results: DMA $i=\alpha+\beta_{\mathrm{MKT}} \mathrm{MKT}+\beta_{\mathrm{SMB}} \mathrm{SMB}+\beta_{\mathrm{HML}} \mathrm{HML}$

$\begin{array}{llllllllllll}\alpha & 1.44 & 1.03 & 0.86 & 0.70 & 0.54 & 0.48 & 0.36 & 0.20 & 0.33 & 0.24 & 0.62\end{array}$

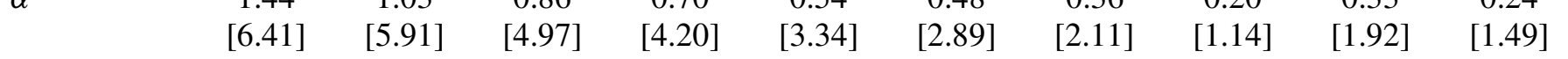

$\begin{array}{llllllllll}\beta_{\text {MKT }} & -0.51 & -0.62 & -0.62 & -0.60 & -0.57 & -0.54 & -0.49 & -0.53 & -0.47\end{array}$

$\begin{array}{lllllllllll}-0.51 & -0.62 & -0.62 & -0.60 & -0.57 & -0.54 & -0.49 & -0.53 & -0.47 & -0.50 & -0.54\end{array}$

$\beta_{\mathrm{SMB}}$

$\left[\begin{array}{llllllllllll}-9.79] & {[-15.4]} & {[-15.4]} & {[-15.6]} & {[-15.2]} & {[-14.2]} & {[-12.2]} & {[-13.3]} & {[-11.9]} & {[-13.5]}\end{array}\right.$

$\begin{array}{llllllllll}-1.00 & -0.86 & -0.85 & -0.84 & -0.81 & -0.72 & -0.73 & -0.64 & -0.63 & -0.33\end{array}$

$\left[\begin{array}{llllllllll}-13.5] & {[-15.0]} & {[-14.9]} & {[-15.1]} & {[-15.2]} & {[-13.3]} & {[-12.7]} & {[-11.2]} & {[-11.0]} & {[-6.36]}\end{array}\right.$

$\beta_{\mathrm{HML}}$

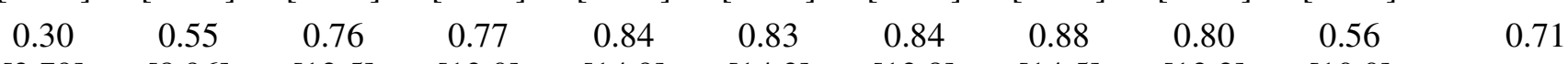

$\left[\begin{array}{llllllllll}{[3.79]} & {[8.96]} & {[12.5]} & {[13.0]} & {[14.9]} & {[14.3]} & {[13.8]} & {[14.5]} & {[13.2]} & {[10.0]}\end{array}\right.$

$\begin{array}{lllllllllll}\text { Adj. }-R^{2}(\%) & 46.6 & 63.6 & 66.8 & 67.8 & 69.1 & 65.6 & 62.0 & 62.6 & 58.7 & 50.8\end{array}$

GRS p-value: $0.0 \%$

Panel E: Conditional three-factor regression results: $\mathrm{DMA}_{i}=\alpha+\beta_{\mathrm{MKT}} \mathrm{MKT}+\beta_{\mathrm{PMU}_{i}} \mathrm{PMU}_{i}+\beta_{\mathrm{VMG}_{i}} \mathrm{VMG}_{i}$

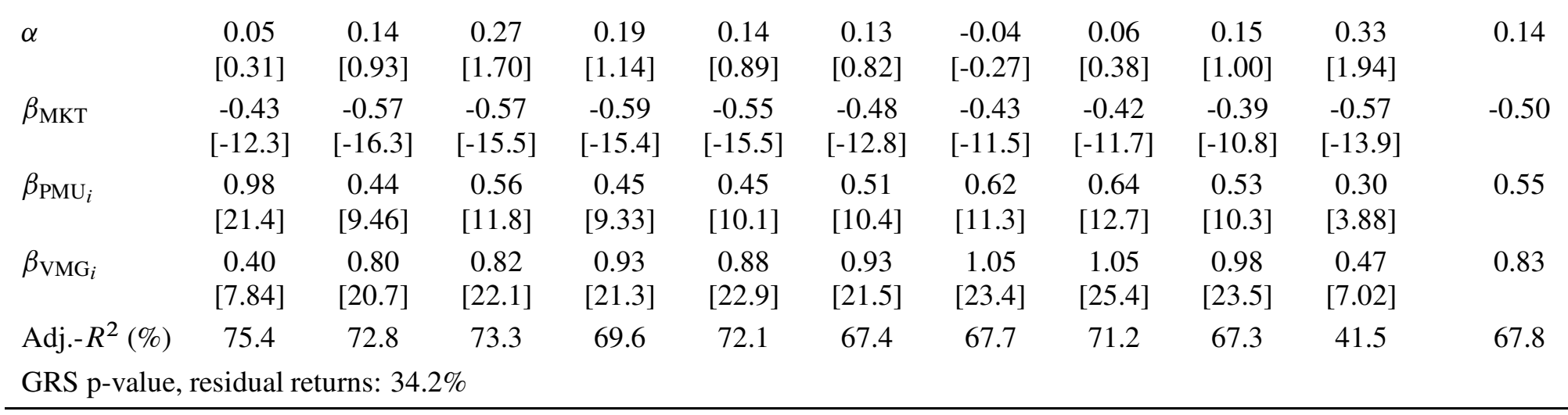


Panel E compares the performance of the defensive strategies constructed within size deciles to the performance of similarly constructed profitability and value strategies. These profitable-minus-unprofitable (PMU) and value-minus-growth (VMG) strategies are formed using the same methodology as the defensive strategies, but the positions in each strategy are selected on the basis of profitability ([GP-SGA]/A) or valuations (B/M) instead of volatility. None of the defensive strategies yield significant abnormal returns relative to similarly constructed profitability and value strategies, even after accounting for the hedge they provide for the market. All of the defensive strategies have highly significant positive loadings on profitability, and accounting for profitability increases the strategies' loadings on value. As a result of these large profitability and value loadings, none of the defensive strategies generates significant abnormal returns, despite having market betas averaging -0.50. A GRS test fails to reject that the three-factor residual returns to the ten strategies are jointly zero (p-value of $34.2 \%)$

While the returns of the ten defensive strategies constructed within size deciles are not abnormal relative to similarly constructed profitability and value strategies, the performance of profitability and value strategies cannot be similarly explained using defensive strategies. Table 5 shows that the profitability (value) strategies have abnormal returns, relative to a model that accounts for the market, value (profitability) strategies, and defensive strategies, that average twice as large as the abnormal returns observed on the defensive strategies in Panel E of Table 4. GRS tests in both cases also strongly reject that the three-factor residual returns to the ten strategies are jointly zero, implying that value and profitability are both outside of the span of defensive strategies, the market, and each other. 
Table 5. Spanning tests of value, profitability, and volatility-based defensive strategies, constructed within size deciles

The table reports the performance of value-minus-growth (VMG) and profitable-minus-unprofitable (PMU) strategies, constructed within each NYSE size decile by buying (selling) the $30 \%$ of stocks with the lowest (highest) valuations (B/M) and profitability ([GP-SGA]/A), respectively. It also reports performance of both sets of strategies relative to the market, each other, and similarly constructed defensive strategies (defensiveminus-aggressive [DFA], defined using estimated volatility). All portfolios are rebalanced monthly, and returns are value-weighted and ignore transaction costs. The sample covers January 1986 to December 2013.

\begin{tabular}{|c|c|c|c|c|c|c|c|c|c|c|c|}
\hline & \multicolumn{10}{|c|}{ Size decile } & \multirow[b]{2}{*}{ Mean } \\
\hline & (1) & (2) & (3) & (4) & (5) & (6) & (7) & (8) & (9) & $(10)$ & \\
\hline \multicolumn{12}{|c|}{ Panel A: Value strategy average monthly excess returns, by size deciles } \\
\hline $\mathrm{E}\left[\mathrm{VMG}_{i}\right]$ & $\begin{array}{c}0.99 \\
{[5.90]}\end{array}$ & $\begin{array}{c}0.82 \\
{[4.42]}\end{array}$ & $\begin{array}{c}0.57 \\
{[2.95]}\end{array}$ & $\begin{array}{c}0.43 \\
{[2.55]}\end{array}$ & $\begin{array}{c}0.51 \\
{[2.81]}\end{array}$ & $\begin{array}{c}0.44 \\
{[2.54]}\end{array}$ & $\begin{array}{c}0.38 \\
{[2.36]}\end{array}$ & $\begin{array}{c}0.15 \\
{[0.91]}\end{array}$ & $\begin{array}{c}0.24 \\
{[1.45]}\end{array}$ & $\begin{array}{c}0.11 \\
{[0.71]}\end{array}$ & 0.46 \\
\hline \multicolumn{12}{|c|}{ GRS p-value: $0.0 \%$} \\
\hline \multicolumn{12}{|c|}{ Panel B: Conditional three-factor regression results: $\mathrm{VMG}_{i}=\alpha+\beta_{\mathrm{MKT}} \mathrm{MKT}+\beta_{\mathrm{PMU}_{i}} \mathrm{PMU}_{i}+\beta_{\mathrm{DMA}_{i} \mathrm{DMA}_{i}}$} \\
\hline$\alpha$ & $\begin{array}{c}0.54 \\
{[4.39]}\end{array}$ & $\begin{array}{c}0.37 \\
{[2.94]}\end{array}$ & $\begin{array}{c}0.23 \\
{[1.75]}\end{array}$ & $\begin{array}{c}0.25 \\
{[2.13]}\end{array}$ & $\begin{array}{c}0.27 \\
{[2.20]}\end{array}$ & $\begin{array}{c}0.29 \\
{[2.52]}\end{array}$ & $\begin{array}{c}0.33 \\
{[3.07]}\end{array}$ & $\begin{array}{c}0.16 \\
{[1.49]}\end{array}$ & $\begin{array}{c}0.15 \\
{[1.34]}\end{array}$ & $\begin{array}{c}0.26 \\
{[2.50]}\end{array}$ & 0.28 \\
\hline$\beta_{\text {MKT }}$ & $\begin{array}{c}-0.09 \\
{[-2.75]}\end{array}$ & $\begin{array}{c}0.11 \\
{[3.22]}\end{array}$ & $\begin{array}{c}0.10 \\
{[2.79]}\end{array}$ & $\begin{array}{c}0.09 \\
{[2.62]}\end{array}$ & $\begin{array}{c}0.12 \\
{[3.57]}\end{array}$ & $\begin{array}{c}0.03 \\
{[1.11]}\end{array}$ & $\begin{array}{c}0.04 \\
{[1.52]}\end{array}$ & $\begin{array}{c}0.05 \\
{[1.76]}\end{array}$ & $\begin{array}{c}0.03 \\
{[1.05]}\end{array}$ & $\begin{array}{c}-0.13 \\
{[-4.48]}\end{array}$ & 0.04 \\
\hline$\beta_{\mathrm{PMU}_{i}}$ & $\begin{array}{c}0.24 \\
{[4.86]}\end{array}$ & $\begin{array}{c}-0.07 \\
{[-1.75]}\end{array}$ & $\begin{array}{c}-0.25 \\
{[-5.81]}\end{array}$ & $\begin{array}{c}-0.23 \\
{[-6.45]}\end{array}$ & $\begin{array}{c}-0.22 \\
{[-6.03]}\end{array}$ & $\begin{array}{c}-0.37 \\
{[-10.4]}\end{array}$ & $\begin{array}{c}-0.44 \\
{[-11.9]}\end{array}$ & $\begin{array}{c}-0.48 \\
{[-14.0]}\end{array}$ & $\begin{array}{c}-0.40 \\
{[-10.9]}\end{array}$ & $\begin{array}{c}-0.80 \\
{[-23.9]}\end{array}$ & -0.30 \\
\hline$\beta_{\mathrm{DMA}_{i}}$ & $\begin{array}{c}0.25 \\
{[7.84]}\end{array}$ & $\begin{array}{c}0.55 \\
{[20.7]}\end{array}$ & $\begin{array}{c}0.57 \\
{[22.1]}\end{array}$ & $\begin{array}{c}0.49 \\
{[21.3]}\end{array}$ & $\begin{array}{c}0.55 \\
{[22.9]}\end{array}$ & $\begin{array}{c}0.49 \\
{[21.5]}\end{array}$ & $\begin{array}{c}0.48 \\
{[23.4]}\end{array}$ & $\begin{array}{c}0.51 \\
{[25.4]}\end{array}$ & $\begin{array}{c}0.51 \\
{[23.5]}\end{array}$ & $\begin{array}{c}0.17 \\
{[7.02]}\end{array}$ & 0.46 \\
\hline $\operatorname{Adj} .-R^{2}(\%)$ & 50.5 & 56.0 & 57.3 & 54.6 & 56.9 & 56.2 & 58.3 & 62.9 & 58.3 & 54.9 & 56.6 \\
\hline \multicolumn{12}{|c|}{ GRS p-value, residual returns: $0.1 \%$} \\
\hline
\end{tabular}


Table 5 (continued)

Size decile

$\begin{array}{llllllllll}(1) & (2) & (3) & (4) & (5) & (6) & (7) & \text { (8) } & \text { (9) } & \text { (10) }\end{array}$

Panel C: Profitability strategy average monthly excess returns, by size deciles

$\begin{array}{cccccccccccc}\mathrm{E}\left[\mathrm{PMU}_{i}\right] & 0.90 & 0.60 & 0.42 & 0.54 & 0.27 & 0.19 & 0.27 & 0.23 & 0.18 & 0.15 & 0.37 \\ & {[5.07]} & {[4.26]} & {[3.06]} & {[3.85]} & {[1.89]} & {[1.34]} & {[2.12]} & {[1.72]} & {[1.36]} & {[1.10]}\end{array}$

GRS p-value: $0.0 \%$

Panel D: Conditional three-factor regression results: $\mathrm{PMU}_{i}=\alpha+\beta_{\mathrm{MKT}_{\mathrm{MKT}} \mathrm{MK}}+\beta_{\mathrm{PMU}_{i}} \mathrm{VMG}_{i}+\beta_{\mathrm{DMA}_{i}} \mathrm{DMA}_{i}$

\begin{tabular}{|c|c|c|c|c|c|c|c|c|c|c|c|}
\hline$\alpha$ & $\begin{array}{c}0.11 \\
{[1.00]}\end{array}$ & $\begin{array}{c}0.32 \\
{[2.47]}\end{array}$ & $\begin{array}{c}0.21 \\
{[1.66]}\end{array}$ & $\begin{array}{c}0.43 \\
{[3.19]}\end{array}$ & $\begin{array}{c}0.19 \\
{[1.41]}\end{array}$ & $\begin{array}{c}0.23 \\
{[1.85]}\end{array}$ & $\begin{array}{c}0.36 \\
{[3.21]}\end{array}$ & $\begin{array}{c}0.26 \\
{[2.33]}\end{array}$ & $\begin{array}{c}0.22 \\
{[1.89]}\end{array}$ & $\begin{array}{c}0.28 \\
{[3.07]}\end{array}$ & 0.26 \\
\hline$\beta_{\mathrm{MKT}}$ & $\begin{array}{c}0.20 \\
{[7.79]}\end{array}$ & $\begin{array}{c}0.18 \\
{[5.15]}\end{array}$ & $\begin{array}{c}0.19 \\
{[5.60]}\end{array}$ & $\begin{array}{c}0.16 \\
{[4.32]}\end{array}$ & $\begin{array}{c}0.14 \\
{[3.84]}\end{array}$ & $\begin{array}{c}0.03 \\
{[0.95]}\end{array}$ & $\begin{array}{c}-0.01 \\
{[-0.36]}\end{array}$ & $\begin{array}{c}-0.01 \\
{[-0.35]}\end{array}$ & $\begin{array}{c}-0.05 \\
{[-1.60]}\end{array}$ & $\begin{array}{c}-0.17 \\
{[-6.89]}\end{array}$ & 0.07 \\
\hline$\beta_{\mathrm{DMA}_{i}}$ & $\begin{array}{c}0.46 \\
{[21.4]}\end{array}$ & $\begin{array}{c}0.32 \\
{[9.46]}\end{array}$ & $\begin{array}{c}0.36 \\
{[11.8]}\end{array}$ & $\begin{array}{c}0.30 \\
{[9.33]}\end{array}$ & $\begin{array}{c}0.35 \\
{[10.1]}\end{array}$ & $\begin{array}{c}0.32 \\
{[10.4]}\end{array}$ & $\begin{array}{c}0.30 \\
{[11.3]}\end{array}$ & $\begin{array}{c}0.36 \\
{[12.7]}\end{array}$ & $\begin{array}{c}0.31 \\
{[10.3]}\end{array}$ & $\begin{array}{c}0.09 \\
{[3.88]}\end{array}$ & 0.32 \\
\hline$\beta_{\mathrm{VMG}_{i}}$ & $\begin{array}{c}0.18 \\
{[4.86]}\end{array}$ & $\begin{array}{c}-0.08 \\
{[-1.75]}\end{array}$ & $\begin{array}{c}-0.23 \\
{[-5.81]}\end{array}$ & $\begin{array}{c}-0.30 \\
{[-6.45]}\end{array}$ & $\begin{array}{c}-0.28 \\
{[-6.03]}\end{array}$ & $\begin{array}{c}-0.44 \\
{[-10.4]}\end{array}$ & $\begin{array}{c}-0.47 \\
{[-11.9]}\end{array}$ & $\begin{array}{c}-0.55 \\
{[-14.0]}\end{array}$ & $\begin{array}{c}-0.45 \\
{[-10.9]}\end{array}$ & $\begin{array}{c}-0.64 \\
{[-23.9]}\end{array}$ & -0.33 \\
\hline Adj.- $R^{2}(\%)$ & 66.7 & 20.0 & 21.1 & 13.3 & 16.0 & 20.4 & 25.4 & 31.2 & 23.6 & 53.3 & 29.1 \\
\hline
\end{tabular}




\section{Role of small cap growth}

The previous section showed that size, value, and profitability all contribute to defensive strategy performance, because volatile stocks tend to be small, unprofitable growth stocks. This is illustrated simply in Figure 3, which gives the performance of the same five volatility portfolios shown in Figure 1, together with the performance of the market, and the portfolio of those stocks with below NYSE median market capitalization, below NYSE median profitability, and below NYSE median book-to-markets. The figure again shows the poor performance of the most aggressive stocks, but shows that this performance was comparable to that of unprofitable small cap growth stocks. This figure also shows that the performance of the other four portfolios was similar to that of the broad market.

While defensive strategy performance is partially driven by its tendency to exclude small

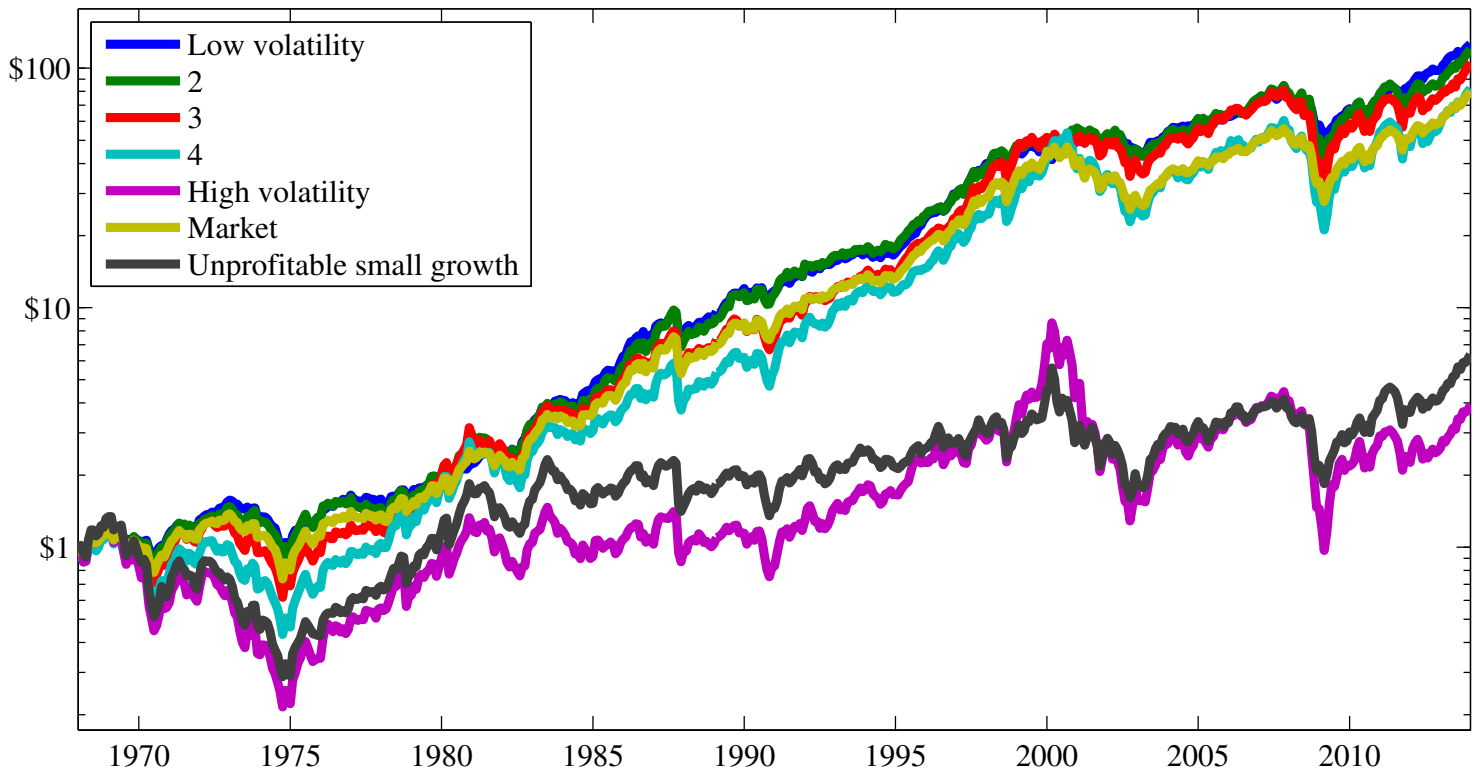

Figure 3. Performance of the volatility portfolios, and unprofitable small growth stocks Growth of \$1 invested in quintile portfolios sorted on volatility, the market, and the portfolio of those stocks with below NYSE median market capitalization, above NYSE median profitability, and above NYSE median book-to-markets. Portfolios are rebalanced monthly. Returns are valueweighted, and ignore transaction costs. The sample covers January 1968 through December 2013. 
cap growth stocks, small cap growth plays an important additional, indirect role in the performance of defensive strategies. While the previous section shows defensive performance is stronger among smaller stocks, this section shows that defensive performance is, after controlling for style, wholly concentrated in the small cap growth sector.

Figure 4 shows the performance of defensive strategies constructed within four broad style universes: small growth, small value, large growth, and large value, where large (small) is defined as above (below) NYSE median market capitalization, and value (growth) is defined by above (below) NYSE median book-to-market. These defensive strategies buy (sell)

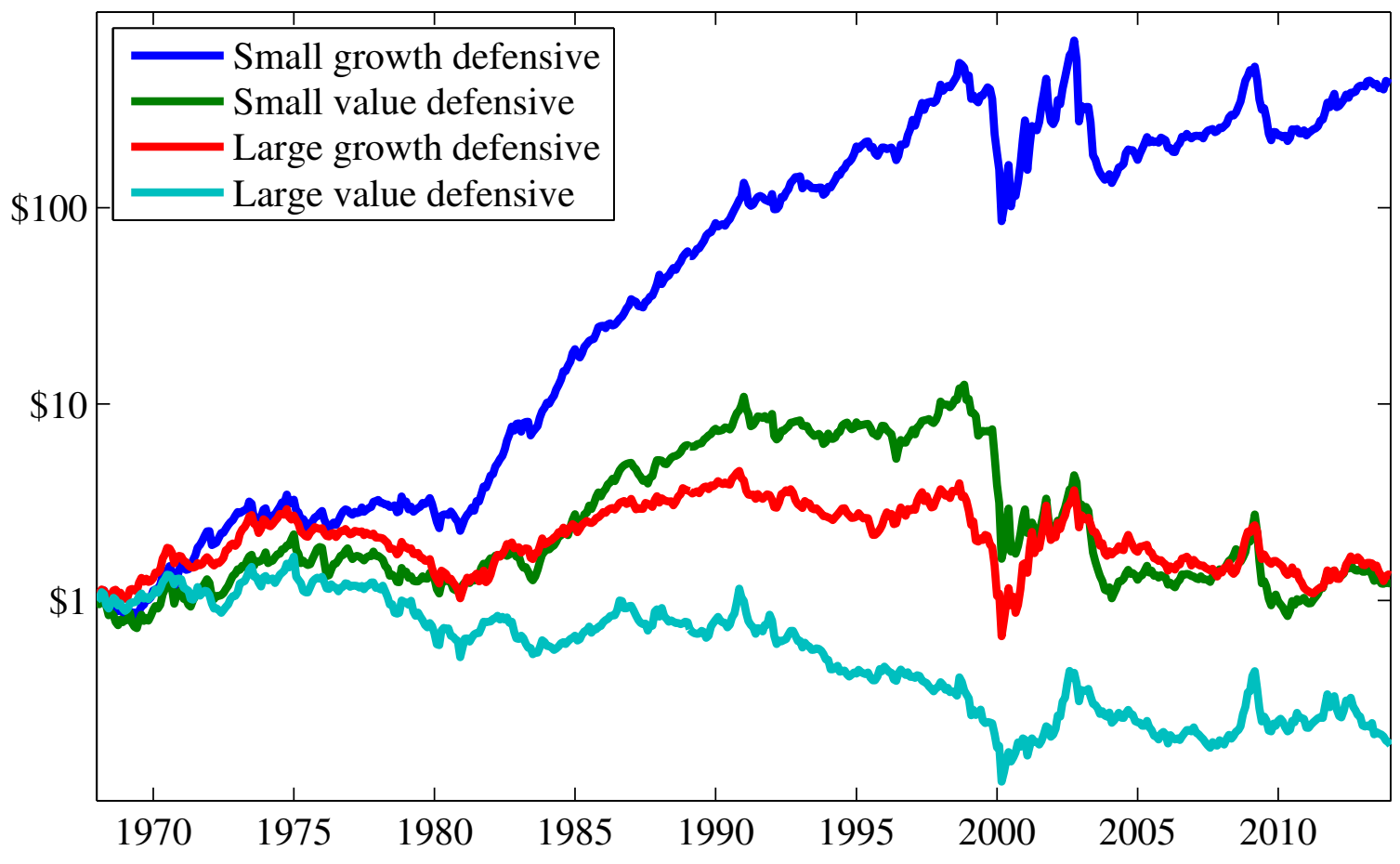

Figure 4. Performance of volatility strategies constructed within style universes

Growth of $\$ 1$ invested in defensive strategies constructed within style universes. Large (small) is defined as above (below) NYSE median market capitalization, and value (growth) is defined by above (below) NYSE median book-to-market. Defensive strategies buy (sell) the $20 \%$ of stocks with the lowest (highest) estimated volatility in each style universe. All portfolios are rebalanced monthly. Returns are value-weighted, and ignore transaction costs. The sample covers January 1968 through December 2013. 
the $20 \%$ of stocks with the lowest (highest) estimated volatility in each style universe. Portfolios are rebalanced monthly. Returns are value-weighted and ignore transaction costs. The sample again covers January 1968 to December 2013.

The figure shows that $\$ 1$ invested in the beginning of 1968 in the defensive strategy constructed within small cap growth, a segment that accounts for on average $38.0 \%$ of names but only $5.4 \%$ of the market by capitalization, would have grown to $\$ 429$, ignoring transaction costs, by the end of 2013. That same dollar invested in defensive strategies constructed in the small cap value or large cap growth universes would have grown to only $\$ 1.22$ or $\$ 1.34$, respectively, a period over which a dollar invested in T-bills grew to \$10.30. That same dollar invested into a defensive strategy constructed using large cap value stocks would have left the investor with only $\$ 0.18$ by the end of 2013 , an $82 \%$ loss of capital over the sample.

In order to understand why the small growth defensive strategy performed so well, it is useful to look at the characteristics of the volatility portfolios within the small growth sector. Time-series average characteristics for these portfolios are reported in Table 6. The table shows extreme valuations and profitabilities for the most volatile small growth stocks. These volatile stocks are on average less than a third as large as the typical small growth stock. The entire portfolio also has negative book equity, negative earnings, and operating profitability less than one fifth that of the next highest volatility portfolio. The large differences in returns between the most and least volatile small growth stocks results from this extreme variation

\section{Table 6. Small growth volatility portfolio characteristics}

The table reports time-series average characteristics of quintile portfolios sorted on volatility, restricted to stocks with below average NYSE median market capitalizations and book-to-markets. The sample covers Jauary 1968 to December 2013.

\begin{tabular}{lccccc}
\hline & \multicolumn{5}{c}{ Volatility quintile decile } \\
\cline { 2 - 6 } & $(\mathrm{H})$ & $(4)$ & $(3)$ & $(2)$ & $(\mathrm{L})$ \\
\hline Firm size $\left(\$ 10^{6}\right)$ & 55 & 120 & 184 & 239 & 299 \\
Valuation $(\mathrm{B} / \mathrm{M})$ & -0.21 & 0.30 & 0.37 & 0.41 & 0.49 \\
Return-on-market equity $(\mathrm{NI} / \mathrm{M})$ & $-43.3 \%$ & $-4.3 \%$ & $2.3 \%$ & $4.9 \%$ & $6.6 \%$ \\
Operating profitability $\left(\frac{\mathrm{GP}-\mathrm{SGA}}{\mathrm{A}}\right)$ & $1.4 \%$ & $7.7 \%$ & $11.8 \%$ & $13.4 \%$ & $9.8 \%$ \\
\hline
\end{tabular}


in valuations and profitabilities. In the other sectors, where defensive stocks do not significantly outperform aggressive stocks, sorting on volatility yields little variation in operating profitability, and in the value sectors the defensive strategies actually tilt to growth, not value.

The extreme variation in valuations and profitabilities that result from sorting small growth stocks on the basis of volatility can only arise, however, because of the extreme variation in these characteristics that exists in this segment, and this variation can just as easily be exploited directly. In fact, Table 7 shows that the small growth defensive strategies' impressive performance was completely unremarkable after controlling for the strategy's value and profitability tilts. The first specification shows that the small growth defensive strategy generated excess returns of more than $1.5 \%$ per month. The second and third specifications show even larger CAPM and Fama and French three-factor alphas, both significant with tstats of six. The fourth specification shows that the small growth defensive strategy's returns are completely explained by the market and small growth profitability and value factors. The fifth specification shows similar results using a two-factor model employing the market and the returns to a strategy that buys (sells) small growth stocks with above (below) both segment median operating profitability and book-to-market.

Figure 5 shows the performance of the small growth defensive strategy, together with the performance of the three-and two-factor replicating portfolios from specifications (4) and (5) of the previous table. The three-factor replicating portfolio holds $\$ 1.29$ of T-bills, and $\$ 0.73$ and $\$ 0.87$ of the small growth stocks with the highest operating profitabilities and book-to-markets, respectively, while shorting $\$ 0.29$ of the market and $\$ 0.73$ and $\$ 0.87$ of the small growth stocks with the lowest operating profitabilities and book-to-markets, respectively. The two-factor replicating portfolio holds $\$ 1.32$ of T-bills and $\$ 1.46$ of small growth stocks with both above segment median operating profitabilities and book-to-markets, while shorting $\$ 0.32$ of the market and $\$ 1.46$ of small growth stocks with both below segment median operating profitabilities and book-to-markets. The figure shows that over the 46 year sample $\$ 1$ invested in the small growth defensive strategy instead of the three- or two-factor replicating portfolios would have grown less ( $\$ 429$, vs. $\$ 560$ and $\$ 1,015)$, and subjected the investor to more volatility (28.8\%, vs. $24.3 \%$ and $24.7 \%)$. 


\section{Table 7. Small growth defensive strategy performance}

The table reports average monthly returns of the small growth defensive-minus-aggressive strategy (DMA $\left.A_{S G}\right)$, and results from time-series regressions of the defensive strategy's returns onto the market; onto the three Fama and French factors; onto a three-factor model using the market, a small growth profitable-minusunprofitable factor $\left(\mathrm{PMU}_{\mathrm{SG}}\right)$, and a small growth value-minus-growth factor $\left(\mathrm{VMG}_{\mathrm{SG}}\right)$; and onto a two-factor model using the market and a small growth profitable value-minus-unprofitable growth factor $\left(\mathrm{PVMUG}_{\mathrm{SG}}\right)$. That is, the table reports results from regressions of the form

$$
\begin{aligned}
& \text { (1) } \mathrm{DMA}_{\mathrm{SG}}=\alpha+\varepsilon \\
& \text { (2) } \mathrm{DMA}_{\mathrm{SG}}=\alpha+\beta_{\mathrm{MKT}} \mathrm{MKT}+\varepsilon \\
& \text { (3) } \mathrm{DMA}_{\mathrm{SG}}=\alpha+\beta_{\mathrm{MKT}} \mathrm{MKT}+\beta_{\mathrm{SMB}} \mathrm{SMB}+\beta_{\mathrm{HML}} \mathrm{HML}+\varepsilon \\
& \text { (4) } \mathrm{DMA}_{\mathrm{SG}}=\alpha+\beta_{\mathrm{MKT}} \mathrm{MKT}+\beta_{\mathrm{PMU}} \mathrm{PMU}_{\mathrm{SG}}+\beta_{\mathrm{VMG}_{\mathrm{SG}}} \mathrm{VMG}_{\mathrm{SG}}+\varepsilon \\
& \text { (5) } \mathrm{DMA}_{\mathrm{SG}}=\alpha+\beta_{\mathrm{MKT}} \mathrm{MKT}+\beta_{\mathrm{PVMUG}_{\mathrm{SG}}} \mathrm{PVMUG}_{\mathrm{SG}}+\varepsilon .
\end{aligned}
$$

Small growth is defined as stocks with below NYSE median market capitalizations and book-to-markets. Defensive (aggressive) is defined as the $20 \%$ of small growth stocks with the lowest (highest) estimated volatility. Profitable (unprofitable) is defined as the $20 \%$ of small growth stocks with the highest (lowest)

\begin{tabular}{|c|c|c|c|c|c|}
\hline & (1) & (2) & (3) & (4) & (5) \\
\hline Constant & $\begin{array}{c}1.51 \\
{[4.12]}\end{array}$ & $\begin{array}{c}1.93 \\
{[5.89]}\end{array}$ & $\begin{array}{c}1.71 \\
{[6.08]}\end{array}$ & $\begin{array}{c}0.13 \\
{[0.67]}\end{array}$ & $\begin{array}{c}-0.02 \\
{[-0.09]}\end{array}$ \\
\hline MKT & & $\begin{array}{c}-0.86 \\
{[-12.2]}\end{array}$ & $\begin{array}{c}-0.50 \\
{[-7.67]}\end{array}$ & $\begin{array}{c}-0.29 \\
{[-6.73]}\end{array}$ & $\begin{array}{c}-0.32 \\
{[-7.16]}\end{array}$ \\
\hline SMB & & & $\begin{array}{c}-1.13 \\
{[-12.1]}\end{array}$ & & \\
\hline HML & & & $\begin{array}{c}0.65 \\
{[6.49]}\end{array}$ & & \\
\hline $\mathrm{PMU}_{\mathrm{SG}}$ & & & & $\begin{array}{c}0.73 \\
{[15.5]}\end{array}$ & \\
\hline $\mathrm{VMG}_{\mathrm{SG}}$ & & & & $\begin{array}{c}0.87 \\
{[13.8]}\end{array}$ & \\
\hline $\mathrm{PVMUG}_{\mathrm{SG}}$ & & & & & $\begin{array}{l}1.46 \\
{[32.1]}\end{array}$ \\
\hline Adj.- $R^{2}$ & & 21.3 & 43.6 & 76.3 & 72.6 \\
\hline
\end{tabular}
operating profitabilities. Value (growth) is defined as the $20 \%$ of small growth stocks with the highest (lowest) book-to-markets. Profitable value (unprofitable growth) is defined as small growth stocks with above (below) segment median operating profitability and book-to-market. All portfolios are rebalanced monthly. Returns are value-weighted and ignore transaction costs. The sample covers January 1968 through December 2013. 




Figure 5. Performance of the small growth defensive strategy, and replicating portfolios based on profitability and value

Growth of $\$ 1$ invested in the small growth defensive strategy, and replicating strategies that buy (sell) small growth stocks with relatively high (low) profitabilities and book-to-markets. Large (small) is defined as above (below) NYSE median market capitalization, and value (growth) is defined by above (below) NYSE median book-to-market. The small growth defensive strategy buys (sells) the $20 \%$ of stocks with the lowest (highest) estimated volatility in the small growth segment. The three-factor replicating portfolio uses the market, a factor that buys (sells) the $20 \%$ of stocks with the highest (lowest) operating profitabilities in the small growth segment, and a factor that buys (sells) the $20 \%$ of stocks with the highest (lowest) book-to-markets in the small growth segment. The two-factor replicating portfolio uses the market and factor that buys (sells) small growth stocks with above (below) both segment median operating profitability book-to-market. All portfolios are rebalanced monthly. Returns are value-weighted and ignore transaction costs. The sample covers January 1968 through December 2013. 


\section{Dynamic hedging}

Some of the best known defensive strategies, such as Frazzini and Pedersen's (2014) bettingagainst-beta strategy, are actively managed in order to keep the strategies close to betaneutral. This suggests the possibility that time-variation in factor exposures, and proper timing to exploit these factors' associated premia, could be important for defensive strategy performance.

Figure 6 shows that defensive (low volatility) and aggressive (high volatility) stocks do have important time-variation in their exposures to the Fama and French factors. Panel A shows the large average spread between aggressive and defensive stocks' market loadings, but shows that this spread was more variable later in the sample. Panel B shows the extreme average spread between aggressive and defensive stocks' SMB loadings, but also shows sharp contractions in this spread around the bear markets of the early 1980's, the early 2000's, and especially during the more recent great recession, when the spread actually briefly turned negative. Panel $\mathrm{C}$ shows the defensive stocks' higher average HML loadings, but shows much more variation in the spread between defensive and aggressive stocks than for the other factor loadings. In fact, for much of the pre-1968 sample defensive strategies tilted strongly to growth, not value, which helps explain why defensive stocks have only provided higher returns than aggressive stocks in the post-1967 sample (for pre-1968 defensive strategy factor loadings see Figure 9, in the Appendix). The extreme defensive strategy growth tilt observed around 2010 is mostly due to a sharp concurrent widening of the volatility spread between the most and least profitable stocks. At this time the high volatility portfolio became increasingly dominated by less profitable stocks, which on average have lower valuations. The defensive strategy's peak HML loading is cut $55 \%$ by accounting for its large negative profitability tilt (i.e., in four-factor rolling regressions, which additionally include a profitable-minusunprofitable factor, constructed in the same manner as HML on the basis of operating profitsto-assets instead of book-to-market). 




Panel B: Rolling SMB beta

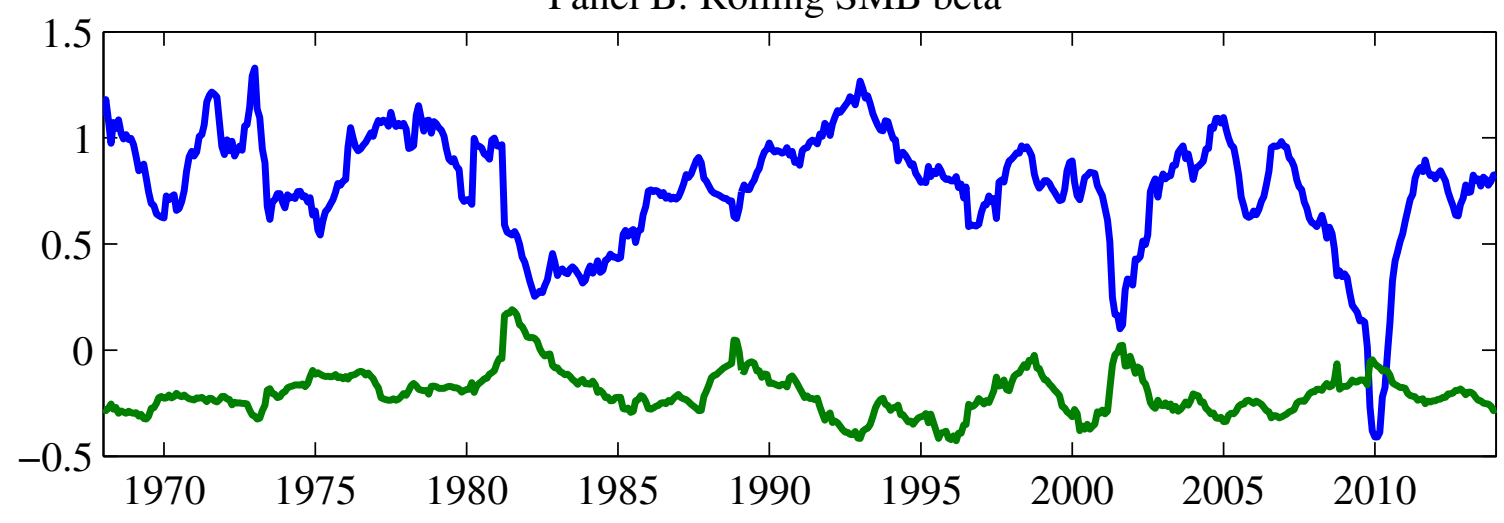

Panel C: Rolling HML beta

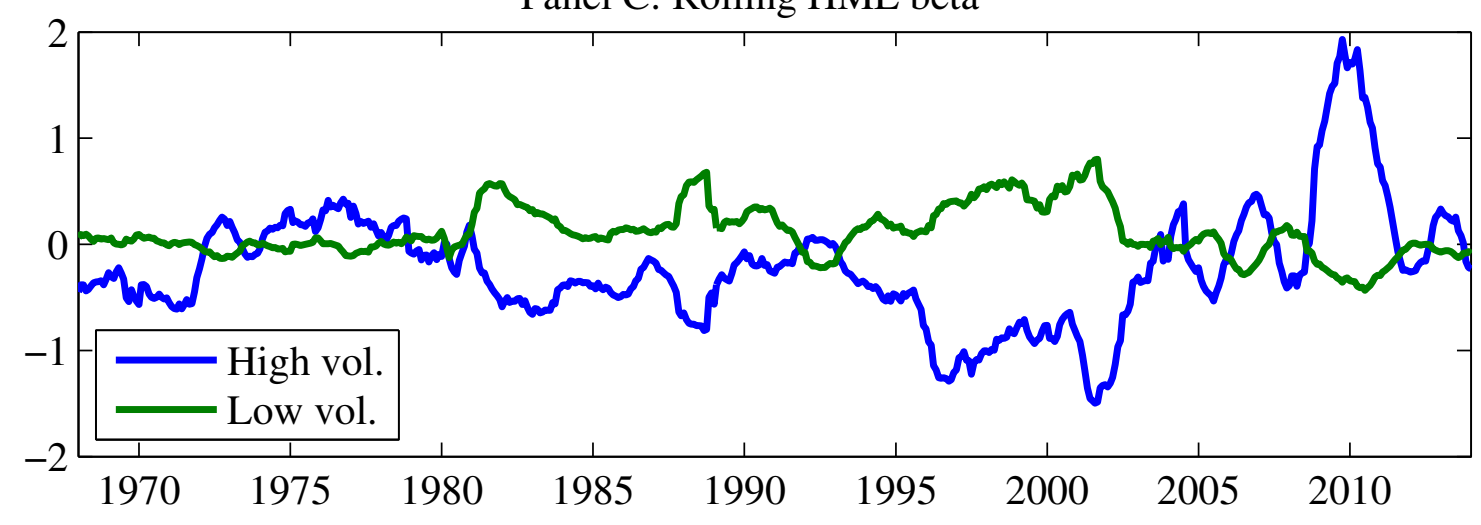

Figure 6. Defensive strategy Fama and French factor loadings

The figure shows the defensive strategy's estimated loadings on the three Fama and French factors over time. Estimates are made using one year of daily data. The defensive strategy holds (shorts) the least (most) volatile quintile of stocks. Quintiles are determined using NYSE breaks, and the defensive strategy is rebalanced monthly. The sample covers January 1968 through December 2013. 




Figure 7. Hedged performance of the volatility portfolios and unprofitable small growth Growth of \$1 invested in hedged volatility portfolios, and a hedged portfolio of unprofitable small growth stocks. Volatility portfolios are determined using NSYE quintile break points. The portfolio of unprofitable small growth stocks includes those with below NYSE median market capitalization, above NYSE median profitability, and above NYSE median book-to-markets. All portfolios are hedged of their exposures to the three Fama and French factors, where these exposures are estimated using the preceding year of daily returns. Portfolios are rebalanced monthly. Returns are valueweighted, and ignore transaction costs. T-bill return is provided for comparison. The sample covers January 1968 through December 2013.

Figure 7 shows that while their is significant time variation in defensive strategies' factor loadings, this variation is basically irrelevant for defensive strategy performance. It shows the performance of the five volatility quintile portfolios, and a portfolio of small unprofitable growth stocks (defined as those stocks that have below NYSE median market capitalization, book-to-market, and operating profitability), all hedged for their exposures to the three Fama and French factors. Dynamic hedging does not improve performance. In fact, outside of the most aggressive stocks dynamically hedging the portfolios yields strategies that perform similarly to T-bills, which is equivalent to saying that the unhedged strategies perform similarly to their dynamically rebalanced three-factor replicating portfolios. The most volatile 
stocks, hedged of their exposure to the three Fama and French factors, significantly underperform T-bills, but do not perform as poorly as the hedged portfolio of small unprofitable growth stocks that they most closely resemble.

\section{Conclusion}

Over the last 45 years defensive stocks have delivered higher returns than the most aggressive stocks, and defensive strategies, at least those based on volatility, have delivered significant Fama and French three-factor alphas. This performance is not at all anomalous, however, after properly controlling for size, relative valuations, and, most critically, profitability. While investors would have benefited from a defensive tilt over the period, these benefits derive effectively from an unprofitable small growth exclusion, which could have been implemented more efficiently, and at lower cost, directly. 


\section{A Additional results}


Figure 8. Pre-1968 performance of volatility and beta quintiles

Growth of $\$ 1$ invested in quintile portfolios sorted on volatility (top panel) and beta (bottom panel). Volatilities and beta are estimated using one year of daily data when available, and five years of monthly data otherwise. Portfolios are rebalanced monthly and ignore transaction costs, and returns are value-weighted. The sample covers January 1931 through December 1967. 


\section{Table 8. Volatility and beta strategy styles (data underlying Figure 2)}

The table reports the time-series average probability that a stock is in each NYSE size and book-to-market quintile, both unconditionally (Panel A), and conditional on being among the most or least risky stocks, where risk is measured using volatility (Panels B and C) or estimated market betas (Panels D and E). That is, the table reports

$$
P\left[s_{l t} \in \mathrm{ME}_{i t} \cap \mathrm{BM}_{j t} \mid s_{l t} \in \mathrm{U}_{t}\right],
$$

where $s_{l t}$ is a random stock $l$ picked at a random time $t, \mathrm{ME}_{i t}$ and $\mathrm{BM}_{j t}$ are market equity quintile $i$ and book-to-market quintile $j$ at time- $t$, respectively, and $\mathrm{U}_{t}$ is an applicable universe. The applicable universe can be the whole market (Panel A), the high and low volatility quintiles (Panels B and C), and the high and low market beta quintiles (Panels D and E). Volatilities and market betas are estimated using one year of daily data, and portfolios formed on the basis of these variables are determined using NYSE break points. The sample covers January 1968 through December 2013. Probabilities are given in percent.

\begin{tabular}{|c|c|c|c|c|c|}
\hline Style & Deep value & Value & Blend & Growth & High growth \\
\hline \multicolumn{6}{|c|}{ Panel A: All stocks } \\
\hline Giant & 0.72 & 1.17 & 1.36 & 1.75 & 2.68 \\
\hline Large & 0.95 & 1.42 & 1.68 & 2.09 & 2.55 \\
\hline Mid & 1.26 & 1.80 & 2.16 & 2.50 & 2.92 \\
\hline Small & 2.13 & 2.76 & 3.04 & 3.13 & 3.88 \\
\hline Micro & 16.8 & 10.3 & 8.58 & 8.58 & 13.7 \\
\hline \multicolumn{6}{|c|}{ Panel B: High volatility stocks } \\
\hline Giant & 0.06 & 0.04 & 0.07 & 0.11 & 0.50 \\
\hline Large & 0.19 & 0.20 & 0.25 & 0.45 & 1.15 \\
\hline Mid & 0.53 & 0.45 & 0.61 & 1.04 & 2.38 \\
\hline Small & 1.27 & 1.17 & 1.53 & 2.25 & 4.63 \\
\hline Micro & 22.6 & 11.3 & 10.6 & 12.4 & 24.2 \\
\hline \multicolumn{6}{|c|}{ Panel C: Low volatility stocks } \\
\hline Giant & 2.87 & 4.88 & 4.53 & 5.27 & 6.46 \\
\hline Large & 2.79 & 4.81 & 4.39 & 4.06 & 2.65 \\
\hline Mid & 2.94 & 4.53 & 4.11 & 3.14 & 1.78 \\
\hline Small & 2.85 & 4.78 & 3.34 & 1.84 & 1.15 \\
\hline Micro & 9.50 & 8.04 & 5.02 & 2.56 & 1.73 \\
\hline
\end{tabular}


Table 8 (continued)

\begin{tabular}{lccccc}
\hline \multicolumn{1}{l}{ Style } & Deep value & Value & Blend & Growth & High growth \\
\hline \multicolumn{2}{l}{ Panel D: High beta stocks } & & & & \\
Giant & 0.48 & 0.73 & 1.01 & 1.69 & 3.27 \\
Large & 0.89 & 1.07 & 1.52 & 2.22 & 4.25 \\
Mid & 1.32 & 1.38 & 2.03 & 3.00 & 5.61 \\
Small & 2.31 & 2.31 & 2.99 & 4.44 & 7.52 \\
Micro & 9.83 & 6.28 & 7.07 & 9.09 & 17.7 \\
Panel E: Low beta stocks & & & & \\
Giant & 0.62 & 1.23 & 0.99 & 0.97 & 1.30 \\
Large & 0.75 & 1.50 & 1.41 & 1.16 & 1.02 \\
Mid & 1.12 & 1.89 & 1.77 & 1.41 & 1.06 \\
Small & 1.70 & 2.79 & 2.39 & 1.75 & 1.43 \\
Micro & 26.3 & 15.1 & 10.5 & 8.3 & 11.7 \\
\hline
\end{tabular}

\section{Table 9. Market beta correlates}

The table reports Fama and MacBeth (1973) regressions of volatility onto variables known to predict crosssectional variation in returns. Because of the persistence in the variables Newey and West t-statistics are reported, calculated using 60 monthly lags. The sample covers January 1968 through December 2013.

\begin{tabular}{lccccc}
\hline Predictor variable & $(1)$ & $(2)$ & $(3)$ & $(4)$ & $(5)$ \\
\hline Size $(\ln (\mathrm{ME}))$ & 0.07 & & & & 0.14 \\
& {$[4.82]$} & & & & {$[15.7]$} \\
Value $(\ln (\mathrm{B} / \mathrm{M}))$ & & -0.17 & & & -0.06 \\
& & {$[-8.96]$} & & & $0.4 .34]$ \\
Profitability $\left(\frac{\mathrm{GP}-\mathrm{SGA}}{\mathrm{A}}\right)$ & & & 0.07 & & 0.20 \\
& & {$[0.63]$} & & {$[3.26]$} \\
Leverage (B/A) & & & 0.54 & 1.02 \\
& & & & {$[3.07]$} & {$[5.49]$} \\
Mean- $R^{2}(\%)$ & 8.6 & 6.2 & 1.0 & 8.1 & 26.7 \\
\hline
\end{tabular}


Table 10. Operating profitability portfolio performance

The table reports time-series average characteristics (Panel A), monthly average excess returns (Panel B), and results of time-series regressions using the CAPM and the Fama and French three-factor model (Panels C and D, respectively), of quintile portfolios sorted on enterprise level operating profitability, $\frac{\mathrm{REV}-\mathrm{COGS}-\mathrm{SGA}}{\mathrm{A}}$. Portfolios are rebalanced annually, at hte end of June, using NYSE breaks. Returns are value-weighted, and ignore transaction costs. The sample includes all NYSE, NASDAQ, and AMEX common stocks, and covers January 1968 through December 2013.

\begin{tabular}{lccccc}
\hline & \multicolumn{5}{c}{ Beta quintiles } \\
\cline { 2 - 6 } & $(\mathrm{H})$ & $(2)$ & $(3)$ & $(4)$ & $(\mathrm{L})$ \\
\hline \multicolumn{5}{l}{ Panel A: Portfolio characteristics } \\
Firms (\%) & 38.2 & 16.3 & 14.6 & 14.4 & 16.5 \\
Cap. $(\%)$ & 13.3 & 11.2 & 16.7 & 22.7 & 36.1 \\
B/M & 0.90 & 0.82 & 0.67 & 0.53 & 0.34 \\
$\overline{\mathrm{ME}}_{2013}\left(\$ 10^{6}\right)$ & 204 & 484 & 643 & 1,025 & 1,200
\end{tabular}

Panel B: Portfolio average monthly excess returns

$\begin{array}{ccccccc}\mathrm{E}\left[R^{e}\right] & 0.35 & 0.46 & 0.55 & 0.52 & 0.55 & 0.19 \\ & {[1.41]} & {[1.94]} & {[2.63]} & {[2.57]} & {[2.78]} & {[1.33]}\end{array}$

Panel C: CAPM regression results

\begin{tabular}{lcccccc}
$\alpha$ & -0.21 & -0.08 & 0.06 & 0.05 & 0.09 & 0.30 \\
& {$[-2.16]$} & {$[-1.12]$} & {$[1.10]$} & {$[0.92]$} & {$[1.58]$} & {$[2.20]$} \\
$\beta_{\text {MKT }}$ & 1.18 & 1.15 & 1.01 & 0.99 & 0.95 & -0.23 \\
\multirow{2}{*}{ Adj.- $R^{2}(\%)$} & {$[56.6]$} & {$[71.0]$} & {$[81.2]$} & {$[87.0]$} & {$[73.4]$} & {$[-7.86]$} \\
& 85.5 & 90.3 & 92.4 & 93.3 & 90.8 & 10.2
\end{tabular}

Panel D: Three-factor model regression results

\begin{tabular}{lcccccc}
$\alpha$ & -0.39 & -0.19 & 0.04 & 0.08 & 0.24 & 0.62 \\
& {$[-4.48]$} & {$[-2.80]$} & {$[0.67]$} & {$[1.47]$} & {$[4.75]$} & {$[5.51]$} \\
$\beta_{\text {MKT }}$ & 1.20 & 1.14 & 1.02 & 0.98 & 0.92 & -0.28 \\
& {$[60.4]$} & {$[72.7]$} & {$[75.3]$} & {$[80.0]$} & {$[80.6]$} & {$[-10.7]$} \\
$\beta_{\text {SMB }}$ & 0.25 & 0.23 & 0.03 & -0.02 & -0.14 & -0.38 \\
\multirow{2}{*}{$\beta_{\text {HML }}$} & {$[8.61]$} & {$[10.1]$} & {$[1.48]$} & {$[-1.12]$} & {$[-8.23]$} & {$[-10.2]$} \\
\multirow{2}{*}{ Adj.- $R^{2}(\%)$} & 0.33 & 0.19 & 0.05 & -0.06 & -0.27 & -0.61 \\
& {$[11.0]$} & {$[7.82]$} & {$[2.26]$} & {$[-3.16]$} & {$[-15.7]$} & {$[-15.3]$} \\
\hline
\end{tabular}




\section{Table 11. Predicting volatility with other profitability measures}

The table reports Fama and MacBeth (1973) regressions of volatility onto various profitability measures (Panel A), and onto the components of the primary profitability measure employed in this paper (Panel B). GP is gross profitability, defined as revenues (REV) minus cost of goods sold (COGS); SGA is selling, general, and administrative costs; IE is total interest expense; R\&D is research and development expenditures; NI is net income; and A and BE are book assets and book equity, respectively. Because of the persistence in the variables Newey and West t-statistics are reported, calculated using 60 monthly lags. The sample covers January 1968 through December 2013.

\begin{tabular}{|c|c|c|c|c|c|}
\hline Regressors & $(1)$ & $(2)$ & (3) & (4) & $(5)$ \\
\hline \multicolumn{6}{|c|}{ Panel A: Alternative profitability measures } \\
\hline$(\mathrm{GP}-\mathrm{SGA}) / \mathrm{A}$ & $\begin{array}{c}-0.45 \\
{[-10.2]}\end{array}$ & & & & \\
\hline GP/A & & $\begin{array}{c}-0.05 \\
{[-3.19]}\end{array}$ & & & \\
\hline$(\mathrm{GP}-\mathrm{SGA}-\mathrm{IE}) / \mathrm{BE}$ & & & $\begin{array}{c}-0.00 \\
{[-3.39]}\end{array}$ & & \\
\hline$(\mathrm{GP}-\mathrm{SGA}+\mathrm{R} \& \mathrm{D}) / \mathrm{A}$ & & & & $\begin{array}{c}-0.41 \\
{[-8.90]}\end{array}$ & \\
\hline $\mathrm{NI} / \mathrm{BE}$ & & & & & $\begin{array}{c}-0.00 \\
{[-3.60]}\end{array}$ \\
\hline Mean- $\hat{R}^{2}(\%)$ & 9.3 & 0.6 & 0.1 & 6.5 & 0.2 \\
\hline \multicolumn{6}{|c|}{ Panel B: Components of (GP-SGA)/A } \\
\hline $\mathrm{REV} / \mathrm{A}$ & $\begin{array}{c}0.01 \\
{[1.51]}\end{array}$ & & & $\begin{array}{c}-0.41 \\
{[-8.90]}\end{array}$ & \\
\hline COGS/A & & $\begin{array}{c}0.03 \\
{[2.87]}\end{array}$ & & $\begin{array}{c}0.42 \\
{[9.59]}\end{array}$ & \\
\hline SGA/A & & & $\begin{array}{c}0.17 \\
{[4.25]}\end{array}$ & $\begin{array}{c}0.49 \\
{[10.8]}\end{array}$ & \\
\hline Mean- $\hat{R}^{2}(\%)$ & 0.5 & 0.7 & 3.8 & 10.9 & \\
\hline
\end{tabular}




\section{Table 12. Beta portfolio performance by size deciles}

The table reports the performance of defensive-minus-aggressive (DMA) strategies, constructed within each NYSE size decile by buying (selling) the $30 \%$ of stocks with the lowest (highest) estimated market betas. It also reports performance of the strategies relative to the CAPM, the Fama and French three-factor model, and relative to the market and similarly constructed profitability and value strategies (profitable-minus-unprofitable [PMU] and value-minus-growth [VMG], formed on the basis of profitability ([GP-SGA]/A) and valuations (B/M), respectively). All portfolios are rebalanced monthly, and returns are value-weighted and ignore transaction costs. The sample covers January 1986 to December 2013.

\begin{tabular}{llllllllllll}
\hline \multicolumn{10}{c}{ Size decile } \\
\cline { 2 - 5 } & $(1)$ & $(2)$ & $(3)$ & $(4)$ & $(5)$ & (6) & $(7)$ & (8) & (9) & (10) & Mean
\end{tabular}

Panel A: Size portfolio characteristics

$\begin{array}{lcccccccccc}\text { Names }(\%) & 48.7 & 12.2 & 8.1 & 6.4 & 5.4 & 4.5 & 4.1 & 3.8 & 3.5 & 3.4 \\ \text { Cap. }(\%) & 1.8 & 1.7 & 1.9 & 2.4 & 3.0 & 3.8 & 5.2 & 8.0 & 13.7 & 58.5 \\ \text { ME }_{2013}\left(\$ 10^{6}\right) & 13 & 53 & 93 & 148 & 224 & 330 & 488 & 806 & 1,613 & 7,812\end{array}$

Panel B: Volatility strategy average monthly excess returns, by size deciles

$\begin{array}{cccccccccccc}\left.\mathrm{E}^{2} \mathrm{DMA}_{i}\right] & 0.23 & 0.05 & 0.14 & 0.04 & 0.02 & 0.08 & 0.10 & 0.02 & 0.09 & 0.04 & 0.08 \\ & {[0.90]} & {[0.18]} & {[0.53]} & {[0.15]} & {[0.06]} & {[0.32]} & {[0.40]} & {[0.09]} & {[0.37]} & {[0.18]} & \end{array}$

GRS p-value: $87.9 \%$

Panel C: CAPM regression results

\begin{tabular}{|c|c|c|c|c|c|c|c|c|c|c|c|}
\hline$\alpha$ & $\begin{array}{c}0.65 \\
{[3.57]}\end{array}$ & $\begin{array}{c}0.51 \\
{[2.68]}\end{array}$ & $\begin{array}{c}0.62 \\
{[3.14]}\end{array}$ & $\begin{array}{c}0.51 \\
{[2.60]}\end{array}$ & $\begin{array}{c}0.47 \\
{[2.32]}\end{array}$ & $\begin{array}{c}0.51 \\
{[2.66]}\end{array}$ & $\begin{array}{c}0.51 \\
{[2.63]}\end{array}$ & $\begin{array}{c}0.44 \\
{[2.26]}\end{array}$ & $\begin{array}{c}0.48 \\
{[2.48]}\end{array}$ & $\begin{array}{c}0.37 \\
{[2.03]}\end{array}$ & 0.51 \\
\hline$\beta_{\mathrm{MKT}}$ & $\begin{array}{c}-0.88 \\
{[-22.5]}\end{array}$ & $\begin{array}{c}-0.95 \\
{[-23.4]}\end{array}$ & $\begin{array}{c}-0.98 \\
{[-23.2]}\end{array}$ & $\begin{array}{c}-0.97 \\
{[-23.2]}\end{array}$ & $\begin{array}{c}-0.95 \\
{[-21.6]}\end{array}$ & $\begin{array}{c}-0.90 \\
{[-21.5]}\end{array}$ & $\begin{array}{c}-0.85 \\
{[-20.3]}\end{array}$ & $\begin{array}{c}-0.88 \\
{[-20.7]}\end{array}$ & $\begin{array}{c}-0.81 \\
{[-19.3]}\end{array}$ & $\begin{array}{c}-0.68 \\
{[-17.5]}\end{array}$ & -0.89 \\
\hline $\operatorname{Adj} .-R^{2}(\%)$ & 47.8 & 49.8 & 49.4 & 49.3 & 45.8 & 45.5 & 42.7 & 43.8 & 40.3 & 35.7 & 45.0 \\
\hline GRS p-value: & & & & & & & & & & & \\
\hline
\end{tabular}


Table 12 (continued)

\begin{tabular}{|c|c|c|c|c|c|c|c|c|c|c|c|}
\hline & \multicolumn{10}{|c|}{ Size decile } & \multirow[b]{2}{*}{ Mean } \\
\hline & (1) & (2) & (3) & (4) & (5) & (6) & (7) & (8) & (9) & (10) & \\
\hline \multicolumn{12}{|c|}{ Panel D: Fama and French three-factor model regression results: $\mathrm{DMA}_{i}=\alpha+\beta_{\mathrm{MKT}} \mathrm{MKT}+\beta_{\mathrm{SMB}} \mathrm{SMB}+\beta_{\mathrm{HML}} \mathrm{HML}$} \\
\hline$\alpha$ & $\begin{array}{c}0.63 \\
{[3.83]}\end{array}$ & $\begin{array}{c}0.39 \\
{[2.43]}\end{array}$ & $\begin{array}{c}0.40 \\
{[2.48]}\end{array}$ & $\begin{array}{c}0.27 \\
{[1.72]}\end{array}$ & $\begin{array}{c}0.17 \\
{[1.04]}\end{array}$ & $\begin{array}{c}0.22 \\
{[1.44]}\end{array}$ & $\begin{array}{c}0.20 \\
{[1.31]}\end{array}$ & $\begin{array}{c}0.11 \\
{[0.68]}\end{array}$ & $\begin{array}{c}0.17 \\
{[1.02]}\end{array}$ & $\begin{array}{c}0.09 \\
{[0.57]}\end{array}$ & 0.26 \\
\hline$\beta_{\mathrm{MKT}}$ & $\begin{array}{c}-0.72 \\
{[-19.0]}\end{array}$ & $\begin{array}{c}-0.74 \\
{[-19.9]}\end{array}$ & $\begin{array}{c}-0.74 \\
{[-19.5]}\end{array}$ & $\begin{array}{c}-0.72 \\
{[-19.6]}\end{array}$ & $\begin{array}{c}-0.66 \\
{[-18.1]}\end{array}$ & $\begin{array}{c}-0.63 \\
{[-18.0]}\end{array}$ & $\begin{array}{c}-0.59 \\
{[-16.4]}\end{array}$ & $\begin{array}{c}-0.63 \\
{[-16.9]}\end{array}$ & $\begin{array}{c}-0.57 \\
{[-15.2]}\end{array}$ & $\begin{array}{c}-0.52 \\
{[-13.7]}\end{array}$ & -0.65 \\
\hline$\beta_{\mathrm{SMB}}$ & $\begin{array}{c}-0.63 \\
{[-11.7]}\end{array}$ & $\begin{array}{c}-0.69 \\
{[-13.0]}\end{array}$ & $\begin{array}{c}-0.64 \\
{[-11.8]}\end{array}$ & $\begin{array}{c}-0.64 \\
{[-12.2]}\end{array}$ & $\begin{array}{c}-0.64 \\
{[-12.2]}\end{array}$ & $\begin{array}{c}-0.60 \\
{[-12.0]}\end{array}$ & $\begin{array}{c}-0.55 \\
{[-10.7]}\end{array}$ & $\begin{array}{c}-0.45 \\
{[-8.51]}\end{array}$ & $\begin{array}{c}-0.43 \\
{[-7.95]}\end{array}$ & $\begin{array}{c}-0.19 \\
{[-3.39]}\end{array}$ & -0.55 \\
\hline$\beta_{\mathrm{HML}}$ & $\begin{array}{c}0.17 \\
{[2.92]}\end{array}$ & $\begin{array}{c}0.37 \\
{[6.47]}\end{array}$ & $\begin{array}{c}0.55 \\
{[9.55]}\end{array}$ & $\begin{array}{c}0.60 \\
{[10.7]}\end{array}$ & $\begin{array}{c}0.75 \\
{[13.4]}\end{array}$ & $\begin{array}{c}0.72 \\
{[13.6]}\end{array}$ & $\begin{array}{c}0.73 \\
{[13.4]}\end{array}$ & $\begin{array}{c}0.77 \\
{[13.6]}\end{array}$ & $\begin{array}{c}0.73 \\
{[12.6]}\end{array}$ & $\begin{array}{c}0.59 \\
{[10.2]}\end{array}$ & 0.60 \\
\hline Adj.- $R^{2}(\%)$ & 59.5 & 65.0 & 66.0 & 67.5 & 68.1 & 68.0 & 64.8 & 63.5 & 59.4 & 47.8 & 62.9 \\
\hline \multicolumn{12}{|c|}{ GRS p-value: $6.0 \%$} \\
\hline \multicolumn{12}{|c|}{ Panel E: Conditional three-factor regression results: $\mathrm{DMA}_{i}=\alpha+\beta_{\mathrm{MKT} \mathrm{MKT}}+\beta_{\mathrm{PMU}_{i}} \mathrm{PMU}_{i}+\beta_{\mathrm{VMG}_{i}} \mathrm{VMG}_{i}$} \\
\hline$\alpha$ & $\begin{array}{c}-0.24 \\
{[-1.67]}\end{array}$ & $\begin{array}{c}-0.28 \\
{[-1.82]}\end{array}$ & $\begin{array}{c}-0.03 \\
{[-0.19]}\end{array}$ & $\begin{array}{c}-0.10 \\
{[-0.65]}\end{array}$ & $\begin{array}{c}-0.15 \\
{[-0.98]}\end{array}$ & $\begin{array}{c}-0.05 \\
{[-0.32]}\end{array}$ & $\begin{array}{c}-0.11 \\
{[-0.75]}\end{array}$ & $\begin{array}{c}0.03 \\
{[0.23]}\end{array}$ & $\begin{array}{c}0.02 \\
{[0.13]}\end{array}$ & $\begin{array}{c}0.19 \\
{[1.08]}\end{array}$ & -0.07 \\
\hline$\beta_{\mathrm{MKT}}$ & $\begin{array}{c}-0.65 \\
{[-20.2]}\end{array}$ & $\begin{array}{c}-0.70 \\
{[-20.1]}\end{array}$ & $\begin{array}{c}-0.69 \\
{[-19.2]}\end{array}$ & $\begin{array}{c}-0.70 \\
{[-19.3]}\end{array}$ & $\begin{array}{c}-0.64 \\
{[-18.1]}\end{array}$ & $\begin{array}{c}-0.58 \\
{[-16.5]}\end{array}$ & $\begin{array}{c}-0.54 \\
{[-16.2]}\end{array}$ & $\begin{array}{c}-0.54 \\
{[-15.5]}\end{array}$ & $\begin{array}{c}-0.47 \\
{[-14.4]}\end{array}$ & $\begin{array}{c}-0.55 \\
{[-13.4]}\end{array}$ & -0.61 \\
\hline$\beta_{\mathrm{PMU}_{i}}$ & $\begin{array}{c}0.34 \\
{[8.15]}\end{array}$ & $\begin{array}{c}0.27 \\
{[5.85]}\end{array}$ & $\begin{array}{c}0.36 \\
{[7.58]}\end{array}$ & $\begin{array}{c}0.29 \\
{[6.26]}\end{array}$ & $\begin{array}{c}0.30 \\
{[6.68]}\end{array}$ & $\begin{array}{c}0.35 \\
{[7.66]}\end{array}$ & $\begin{array}{c}0.46 \\
{[9.36]}\end{array}$ & $\begin{array}{c}0.49 \\
{[10.2]}\end{array}$ & $\begin{array}{c}0.51 \\
{[10.9]}\end{array}$ & $\begin{array}{c}0.39 \\
{[5.04]}\end{array}$ & 0.38 \\
\hline$\beta_{\mathrm{VMG}_{i}}$ & $\begin{array}{c}0.47 \\
{[10.1]}\end{array}$ & $\begin{array}{c}0.61 \\
{[16.0]}\end{array}$ & $\begin{array}{c}0.63 \\
{[17.0]}\end{array}$ & $\begin{array}{c}0.74 \\
{[17.7]}\end{array}$ & $\begin{array}{c}0.78 \\
{[20.2]}\end{array}$ & $\begin{array}{c}0.80 \\
{[19.6]}\end{array}$ & $\begin{array}{c}0.89 \\
{[22.5]}\end{array}$ & $\begin{array}{c}0.87 \\
{[21.9]}\end{array}$ & $\begin{array}{c}0.88 \\
{[23.2]}\end{array}$ & $\begin{array}{c}0.57 \\
{[8.46]}\end{array}$ & 0.72 \\
\hline Adj.- $R^{2}(\%)$ & 70.2 & 69.6 & 69.9 & 68.8 & 70.6 & 68.4 & 70.6 & 70.5 & 70.7 & 43.1 & 39.3 \\
\hline GRS p-value, & esidual re & urns: 39 . & & & & & & & & & \\
\hline
\end{tabular}


Table 13. Spanning tests of value, profitability, and market beta-based defensive strategies, constructed within size deciles

The table reports the performance of value-minus-growth (VMG) and profitable-minus-unprofitable (PMU) strategies, constructed within each NYSE size decile by buying (selling) the $30 \%$ of stocks with the lowest (highest) valuations (B/M) and profitability ([GP-SGA]/A), respectively. It also reports performance of both sets of strategies relative to the market, each other, and similarly constructed defensive strategies (defensiveminus-aggressive [DFA], defined using estimated market beta). All portfolios are rebalanced monthly, and returns are value-weighted and ignore transaction costs. The sample covers January 1986 to December 2013.

\begin{tabular}{|c|c|c|c|c|c|c|c|c|c|c|c|}
\hline & \multicolumn{10}{|c|}{ Size decile } & \multirow[b]{2}{*}{ Mean } \\
\hline & $(1)$ & (2) & (3) & (4) & $(5)$ & (6) & (7) & (8) & (9) & $(10)$ & \\
\hline \multicolumn{12}{|c|}{ Panel A: Value strategy average monthly excess returns, by size deciles } \\
\hline $\mathrm{E}\left[\mathrm{VMG}_{i}\right]$ & $\begin{array}{c}0.99 \\
{[5.90]}\end{array}$ & $\begin{array}{c}0.82 \\
{[4.42]}\end{array}$ & $\begin{array}{c}0.57 \\
{[2.95]}\end{array}$ & $\begin{array}{c}0.43 \\
{[2.55]}\end{array}$ & $\begin{array}{c}0.51 \\
{[2.81]}\end{array}$ & $\begin{array}{c}0.44 \\
{[2.54]}\end{array}$ & $\begin{array}{c}0.38 \\
{[2.36]}\end{array}$ & $\begin{array}{c}0.15 \\
{[0.91]}\end{array}$ & $\begin{array}{c}0.24 \\
{[1.45]}\end{array}$ & $\begin{array}{c}0.11 \\
{[0.71]}\end{array}$ & 0.46 \\
\hline \multicolumn{12}{|c|}{ GRS p-value: $0.0 \%$} \\
\hline \multicolumn{12}{|c|}{ Panel B: Conditional three-factor regression results: $\mathrm{VMG}_{i}=\alpha+\beta_{\mathrm{MKT}} \mathrm{MKT}+\beta_{\mathrm{PMU}_{i}} \mathrm{PMU}_{i}+\beta_{\mathrm{DMA}_{i} \mathrm{DMA}_{i}}$} \\
\hline$\alpha$ & $\begin{array}{c}0.60 \\
{[5.04]}\end{array}$ & $\begin{array}{c}0.69 \\
{[5.02]}\end{array}$ & $\begin{array}{c}0.49 \\
{[3.39]}\end{array}$ & $\begin{array}{c}0.45 \\
{[3.54]}\end{array}$ & $\begin{array}{c}0.47 \\
{[3.66]}\end{array}$ & $\begin{array}{c}0.41 \\
{[3.42]}\end{array}$ & $\begin{array}{c}0.38 \\
{[3.46]}\end{array}$ & $\begin{array}{c}0.20 \\
{[1.76]}\end{array}$ & $\begin{array}{c}0.22 \\
{[1.97]}\end{array}$ & $\begin{array}{c}0.27 \\
{[2.64]}\end{array}$ & 0.42 \\
\hline$\beta_{\mathrm{MKT}}$ & $\begin{array}{c}0.03 \\
{[0.95]}\end{array}$ & $\begin{array}{c}0.12 \\
{[2.83]}\end{array}$ & $\begin{array}{c}0.11 \\
{[2.45]}\end{array}$ & $\begin{array}{c}0.11 \\
{[2.92]}\end{array}$ & $\begin{array}{c}0.15 \\
{[3.91]}\end{array}$ & $\begin{array}{c}0.08 \\
{[2.40]}\end{array}$ & $\begin{array}{c}0.12 \\
{[3.85]}\end{array}$ & $\begin{array}{c}0.09 \\
{[2.94]}\end{array}$ & $\begin{array}{c}0.09 \\
{[3.10]}\end{array}$ & $\begin{array}{c}-0.11 \\
{[-3.87]}\end{array}$ & 0.08 \\
\hline$\beta_{\mathrm{PMU}_{i}}$ & $\begin{array}{c}0.34 \\
{[9.80]}\end{array}$ & $\begin{array}{c}0.06 \\
{[1.49]}\end{array}$ & $\begin{array}{c}-0.11 \\
{[-2.38]}\end{array}$ & $\begin{array}{c}-0.16 \\
{[-4.14]}\end{array}$ & $\begin{array}{c}-0.14 \\
{[-3.55]}\end{array}$ & $\begin{array}{c}-0.31 \\
{[-8.49]}\end{array}$ & $\begin{array}{c}-0.39 \\
{[-10.6]}\end{array}$ & $\begin{array}{c}-0.44 \\
{[-12.0]}\end{array}$ & $\begin{array}{c}-0.42 \\
{[-11.3]}\end{array}$ & $\begin{array}{c}-0.80 \\
{[-24.3]}\end{array}$ & -0.26 \\
\hline$\beta_{\mathrm{DMA}_{i}}$ & $\begin{array}{c}0.33 \\
{[10.1]}\end{array}$ & $\begin{array}{c}0.52 \\
{[16.0]}\end{array}$ & $\begin{array}{c}0.55 \\
{[17.0]}\end{array}$ & $\begin{array}{c}0.49 \\
{[17.7]}\end{array}$ & $\begin{array}{c}0.55 \\
{[20.2]}\end{array}$ & $\begin{array}{c}0.52 \\
{[19.6]}\end{array}$ & $\begin{array}{c}0.54 \\
{[22.5]}\end{array}$ & $\begin{array}{c}0.54 \\
{[21.9]}\end{array}$ & $\begin{array}{c}0.56 \\
{[23.2]}\end{array}$ & $\begin{array}{c}0.20 \\
{[8.46]}\end{array}$ & 0.48 \\
\hline Adj.- $R^{2}(\%)$ & 53.59 & 46.60 & 47.16 & 47.21 & 51.69 & 52.55 & 56.57 & 57.09 & 57.57 & 56.5 & 53.7 \\
\hline GRS p-value, & sidual re & ns: $0.0 \%$ & & & & & & & & & \\
\hline
\end{tabular}


Table 13 (continued)

Size decile

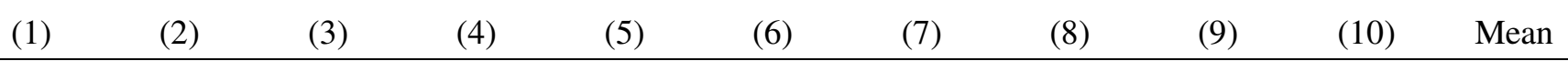

Panel C: Profitability strategy average monthly excess returns, by size deciles

$\begin{array}{cccccccccccc}\mathrm{E}\left[\mathrm{PMU}_{i}\right] & 0.90 & 0.60 & 0.42 & 0.54 & 0.27 & 0.19 & 0.27 & 0.23 & 0.18 & 0.15 & 0.37 \\ & {[5.07]} & {[4.26]} & {[3.06]} & {[3.85]} & {[1.89]} & {[1.34]} & {[2.12]} & {[1.72]} & {[1.36]} & {[1.10]}\end{array}$

GRS p-value: $0.0 \%$

Panel D: Conditional three-factor regression results: $\mathrm{PMU}_{i}=\alpha+\beta_{\mathrm{MKT} \mathrm{MKT}}+\beta_{\mathrm{PMU}_{i}} \mathrm{VMG}_{i}+\beta_{\mathrm{DMA}_{i}} \mathrm{DMA}_{i}$

\begin{tabular}{|c|c|c|c|c|c|c|c|c|c|c|c|}
\hline$\alpha$ & $\begin{array}{c}0.29 \\
{[2.10]}\end{array}$ & $\begin{array}{c}0.47 \\
{[3.40]}\end{array}$ & $\begin{array}{c}0.35 \\
{[2.66]}\end{array}$ & $\begin{array}{c}0.55 \\
{[3.95]}\end{array}$ & $\begin{array}{c}0.30 \\
{[2.11]}\end{array}$ & $\begin{array}{c}0.31 \\
{[2.38]}\end{array}$ & $\begin{array}{c}0.40 \\
{[3.47]}\end{array}$ & $\begin{array}{c}0.30 \\
{[2.53]}\end{array}$ & $\begin{array}{c}0.25 \\
{[2.21]}\end{array}$ & $\begin{array}{c}0.29 \\
{[3.14]}\end{array}$ & 0.35 \\
\hline$\beta_{\mathrm{MKT}}$ & $\begin{array}{c}0.21 \\
{[5.23]}\end{array}$ & $\begin{array}{c}0.15 \\
{[3.75]}\end{array}$ & $\begin{array}{c}0.17 \\
{[4.28]}\end{array}$ & $\begin{array}{c}0.14 \\
{[3.38]}\end{array}$ & $\begin{array}{c}0.11 \\
{[2.66]}\end{array}$ & $\begin{array}{c}0.03 \\
{[0.70]}\end{array}$ & $\begin{array}{c}0.01 \\
{[0.36]}\end{array}$ & $\begin{array}{c}-0.00 \\
{[-0.02]}\end{array}$ & $\begin{array}{c}0.00 \\
{[0.04]}\end{array}$ & $\begin{array}{c}-0.16 \\
{[-6.34]}\end{array}$ & 0.07 \\
\hline$\beta_{\mathrm{DMA}_{i}}$ & $\begin{array}{c}0.31 \\
{[8.15]}\end{array}$ & $\begin{array}{c}0.22 \\
{[5.85]}\end{array}$ & $\begin{array}{c}0.26 \\
{[7.58]}\end{array}$ & $\begin{array}{c}0.23 \\
{[6.26]}\end{array}$ & $\begin{array}{c}0.25 \\
{[6.68]}\end{array}$ & $\begin{array}{c}0.27 \\
{[7.66]}\end{array}$ & $\begin{array}{c}0.30 \\
{[9.36]}\end{array}$ & $\begin{array}{c}0.33 \\
{[10.2]}\end{array}$ & $\begin{array}{c}0.35 \\
{[10.9]}\end{array}$ & $\begin{array}{c}0.11 \\
{[5.04]}\end{array}$ & 0.26 \\
\hline$\beta_{\mathrm{VMG}_{i}}$ & $\begin{array}{c}0.44 \\
{[9.80]}\end{array}$ & $\begin{array}{c}0.06 \\
{[1.49]}\end{array}$ & $\begin{array}{c}-0.09 \\
{[-2.38]}\end{array}$ & $\begin{array}{c}-0.19 \\
{[-4.14]}\end{array}$ & $\begin{array}{c}-0.16 \\
{[-3.55]}\end{array}$ & $\begin{array}{c}-0.37 \\
{[-8.49]}\end{array}$ & $\begin{array}{c}-0.43 \\
{[-10.6]}\end{array}$ & $\begin{array}{c}-0.47 \\
{[-12.0]}\end{array}$ & $\begin{array}{c}-0.45 \\
{[-11.3]}\end{array}$ & $\begin{array}{c}-0.65 \\
{[-24.3]}\end{array}$ & -0.23 \\
\hline Adj.- $R^{2}(\%)$ & 45.50 & 12.38 & 10.45 & 6.27 & 8.03 & 13.91 & 20.77 & 25.05 & 25.01 & 54.2 & 22.2 \\
\hline
\end{tabular}




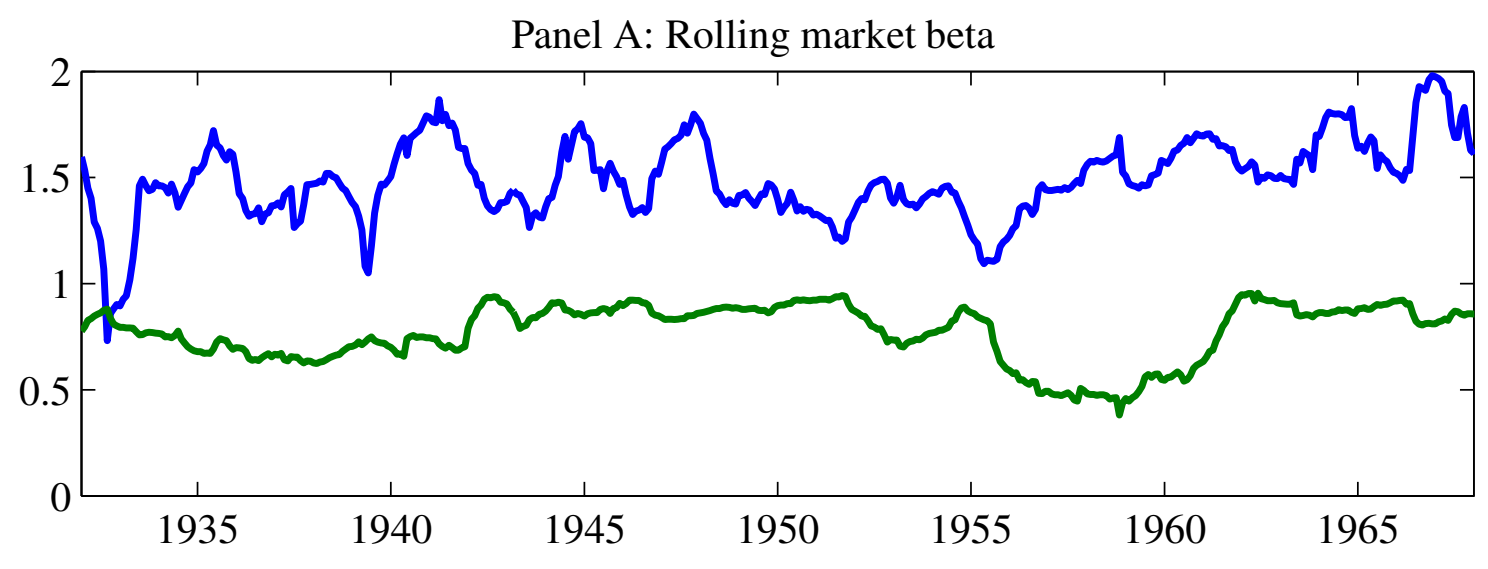

Panel B: Rolling SMB beta



Panel C: Rolling HML beta

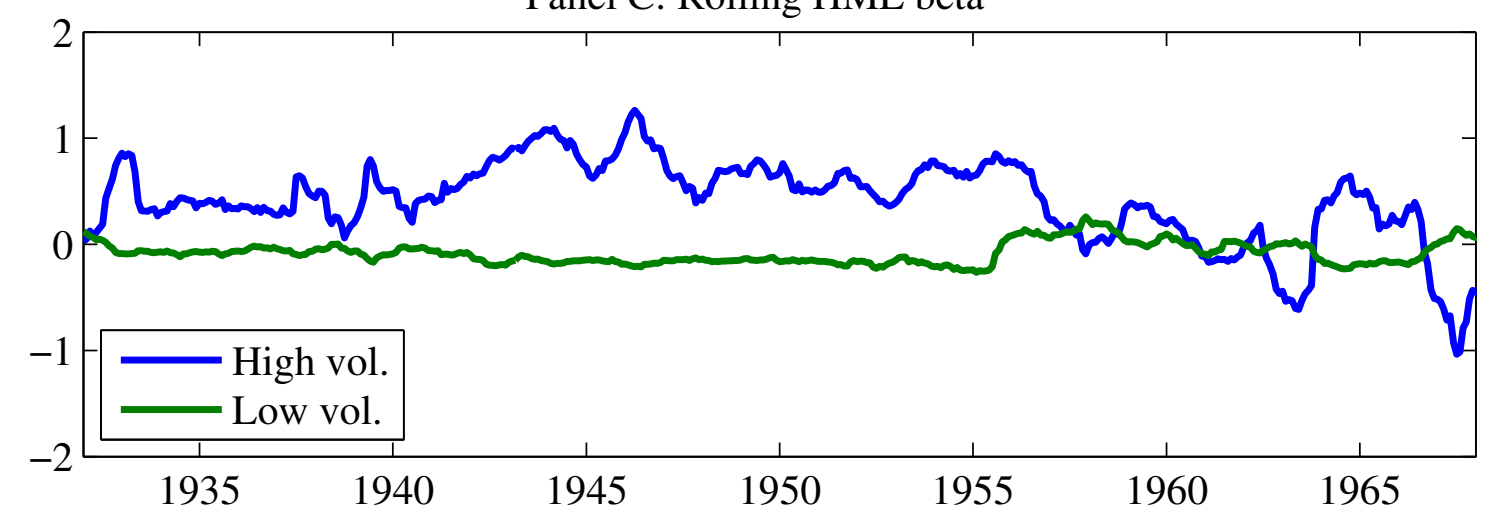

Figure 9. Defensive strategy Fama and French factor loadings, before 1968

The figure shows the defensive strategy's estimated loadings on the three Fama and French factors over time. Estimates are made using one year of daily data. The defensive strategy holds (shorts) the least (most) volatile quintile of stocks. Quintiles are determined using NYSE breaks, and the defensive strategy is rebalanced monthly. The sample covers January 1932 through December 1967. 


\section{References}

[1] Ang, A., Hodrick, R., Xing, Y., Zhang, X., 2006. The cross-section of volatility and expected returns. Journal of Finance 61, 259-299.

[2] Asness, C., Frazzini, A., Pedersen, L.H., 2014. Low-risk investing without industry bets. Financial Analysts Journal 70, 24-41.

[3] Ball, R., Gerakos, J., Linnainmaa, j., Nikolaev, V., 2014. Deflating profitability. University of Chicago working paper.

[4] Baker, M., Bradley, B., Wurgler, J., 2011. Benchmarks as limits to arbitrage: understanding the low-volatility anomaly. Financial Analysts Journal 67, 1-15.

[5] Bali, T.G., Caici, N., 2008. Idiosyncratic volatility and the cross section of expected returns. Journal of Financial and Quantitative Analysis 43, 29-58.

[6] Blitz, D., Van Vliet, P., 2007. The volatility effect: Lower risk without lower return. Journal of Portfolio Management, 102-113.

[7] Black, F., 1972. Capital market equilibrium with restricted borrowing. Journal of Business 45, 444-455.

[8] Black, F., Jensen, M. C., Scholes, M., 1972. The Capital Asset Pricing Model: Some empirical tests. In Studies in the Theory of Capital Markets (Jensen, M.C. editor). Praeger, New York.

[9] Fama, E.F., French, K.R., 1993. Common risk factors in the returns on stocks and bonds. Journal of Financial Economics 33, 3-56.

[10] Fama, E.F., French, K.R., 2014. A five-factor asset pricing model. University of Chicago working paper.

[11] Fama, E. F., MacBeth, J. D., 1973. Risk, return, and equilibrium: empirical tests. Journal of Political Economy 81, 607-636.

[12] Frazzini, A., Pedersen, L.H., 2014. Betting against beta. Journal of Financial Economics 111, $1-25$.

[13] Gibbons, M.R., Ross, S.A., Shanken, J., 1989. A test of the efficiency of a given portfolio. Econometrics 57, 1121-1152.

[14] Li X., Sullivan, R.N., Garcia-Feijóo, L., 2014. The limits to arbitrage and the low-volatility anomaly. Financial Analysts Journal 70, 52-63.

[15] Newey, W.K., West, K.D., 1987. A simple, positive semi-definite, heteroskedasticity and autocorrelation consistent covariance matrix. Econometrica 55, 703-708.

[16] Novy-Marx, R., 2013. The other side of value: The gross profitability premium. Journal of Financial Economics 108, 1-28. 